\title{
Butterfly Pea (Clitoria ternatea), a Cyclotide-Bearing Plant With Applications in Agriculture and Medicine
}

\author{
Georgianna K. Oguis, Edward K. Gilding, Mark A. Jackson and David J. Craik*
}

Institute for Molecular Bioscience, The University of Queensland, St Lucia, QLD, Australia

The perennial leguminous herb Clitoria ternatea (butterfly pea) has attracted significant interest based on its agricultural and medical applications, which range from use as a fodder and nitrogen fixing crop, to applications in food coloring and cosmetics, traditional medicine and as a source of an eco-friendly insecticide. In this article we provide a broad multidisciplinary review that includes descriptions of the physical appearance, distribution, taxonomy, habitat, growth and propagation, phytochemical composition and applications of this plant. Notable amongst its repertoire of chemical components are anthocyanins which give $C$. ternatea flowers their characteristic blue color, and cyclotides, ultra-stable macrocyclic peptides that are present in all tissues of this plant. The latter are potent insecticidal molecules and are implicated as the bioactive agents in a plant extract used commercially as an insecticide. We include a description of the genetic origin of these peptides, which interestingly involve the cooption of an ancestral albumin gene to produce the cyclotide precursor protein. The biosynthesis step in which the cyclic peptide backbone is formed involves an asparaginyl endopeptidase, of which in C. ternatea is known as butelase-1. This enzyme is highly efficient in peptide ligation and has been the focus of many recent studies on peptide ligation and cyclization for biotechnological applications. The article concludes with some suggestions for future studies on this plant, including the need to explore possible synergies between the various peptidic and non-peptidic phytochemicals.

Specialty section:

This article was submitted to Plant Metabolism

and Chemodiversity,

a section of the journal

Frontiers in Plant Science

Received: 15 January 2019

Accepted: 29 April 2019

Published: 28 May 2019

Citation:

Oguis GK, Gilding EK, Jackson MA and Craik DJ (2019) Butterfly Pea (Clitoria ternatea), a Cyclotide-Bearing Plant With

Applications in Agriculture and Medicine.

Front. Plant Sci. 10:645. doi: 10.3389/fp/s.2019.00645

\section{INTRODUCTION}

Clitoria ternatea, commonly known as butterfly pea, is a perennial herbaceous plant from the Fabaceae family. It has recently attracted a lot of interest as it has potential applications both in modern medicine and agriculture, and as a source of natural food colorants and antioxidants. C. ternatea has long been cultivated as a forage and fodder crop, and early studies assessed the plant for these purposes (Reid and Sinclair, 1980; Barro and Ribeiro, 1983; Hall, 1985). Numerous field trials in Queensland, Australia, eventually led to the registry of C. ternatea cv. 'Milgarra' (Oram, 1992), the only cultivar in Australia that was released for grazing purposes (Conway and Doughton, 2005). Additionally, C. ternatea has been widely used in traditional medicine, particularly as a supplement to enhance cognitive functions and alleviate symptoms of numerous ailments including fever, inflammation, pain, and diabetes (Mukherjee et al., 2008). 
In as early as the 1950 s, studies on C. ternatea sought to elucidate its pharmacological activities, phytochemical composition and active constituents (Grindley et al., 1954; Piala et al., 1962; Kulshreshtha and Khare, 1967; Morita et al., 1976). The novel C. ternatea anthocyanins termed "ternatins" which render $C$. ternatea flowers with their vivid blue color, were first isolated in 1985 (Saito et al., 1985). Following further isolation and structural characterization of numerous other ternatins, the ternatin biosynthetic pathway was postulated a decade later (Terahara et al., 1998). In 2003, comparison of C. ternatea lines bearing different floral colors provided insights into the role of acylation on C. ternatea floral color determination (Kazuma et al., 2003a). The abundance of these unique anthocyanins alongside other secondary metabolites in C. ternatea makes the plant an ideal source of natural additives that can enhance the appearance and nutritive values of consumer products (Pasukamonset et al., 2016, 2017, 2018; Siti Azima et al., 2017). Although a number of recent studies has endeavored to elucidate the pharmacological activities of C. ternatea (Adhikary et al., 2017; Kavitha, 2018; Singh et al., 2018), the contribution of individual extract components on any bioactivity measured remains unknown.

Figure 1 summarizes some of the key agricultural and biochemical studies conducted on C. ternatea from the $1950 \mathrm{~s}$ to the present, providing a convenient timeline of discoveries. The corresponding references to the key studies and milestones are listed in Table 1. In recent years, the small circular defense molecules called cyclotides, in C. ternatea (Nguyen et al., 2011; Poth et al., 2011a,b; Nguyen et al., 2014) have fueled scientific innovations that may have impact in modern agriculture, biotechnology and medicine. In 2017, Sero- $\mathrm{X}^{\circledR}$, a cyclotide-containing eco-friendly pesticide made from extracts of C. ternatea, was approved for commercial use in Australia ${ }^{1}$. In addition, the $C$. ternatea cyclotide processing enzyme, butelase1 , which is the fastest ligase known to date and is capable of ligating peptides across a vast range of sizes (26 to $>200$ residues), can potentially be used in the large scale synthesis of macrocycle libraries and peptide-based pharmaceuticals (Nguyen et al., 2014, 2015).

\section{Plant Description}

Clitoria ternatea produces pentamerous zygomorphic peashaped flowers with a tubular calyx consisting of five sepals which are fused about two thirds of their length. The showy corollae consists of five free petals, with one large and rounded banner, two wrinkled wings which are often half the length of the banner and two white keels which aid in protecting the floral organs (Cobley, 1956; Biyoshi and Geetha, 2012) (Figure 2A). The corollae are most often dark blue in color but may also occur in white and various blue and white shades in between (Morris, 2009; Biyoshi and Geetha, 2012). The diadelphous C. ternatea stamens consist of 10 filaments where nine are fused and one is free lying (Cobley, 1956; Biyoshi and Geetha, 2012). Attached to each filament is a pollen-bearing white anther, which consists of four lobes (Cobley, 1956; Pullaiah, 2000). C. ternatea produces a

${ }^{1}$ https://innovate-ag.com.au/ monocarpellary ovary bearing ten ovules (Pullaiah, 2000; Biyoshi and Geetha, 2012). Surmounting this is a long and thick style with a bent tip (Cobley, 1956; Biyoshi and Geetha, 2012). C. ternatea pods are narrow and flattened with pointy tips, and they typically contain around 10 seeds (Cobley, 1956) (Figure 2B). The seeds contain palmitic acid (19\%), stearic acid (10\%), oleic acid (51$52 \%$ ), linoleic acid (17\%) and linolenic acid (4\%) (Grindley et al., 1954; Joshi et al., 1981). The caloric content of the seed is reported to be around $500 \mathrm{cal} / 100 \mathrm{~g}$ (Joshi et al., 1981). C. ternatea produces pinnate compound leaves that are obovate and entire with emarginate tips (Taur et al., 2010) (Figure 2C). The epidermis on both leaf surfaces consist of a single layer of cells protected by a thick cuticle and with trichome outgrowths (Taur et al., 2010). A layer of palisade cells, lignified xylem and paracytic stomata lie underneath the upper epidermis (Taur et al., 2010). C. ternatea produces an extensive deep-root system, which enables the plant to survive up to 7-8 months of drought (Cobley, 1956). The roots also produce large nodules for nitrogen fixation (Cobley, 1956) (Figure 2D).

\section{Taxonomy, Geographic Distribution and Habitat}

The genus Clitoria occurs in tropical and subtropical environments across the globe. The number of subfamilial taxa remains unclear, and as in the case of Clitoria, the descriptions of species and citations of type specimens are noted as being incomplete or incorrect according to Fantz (1977). Thus, it is difficult to estimate species richness of the genus. Within Clitoria, three subgenera have been described and held as valid according to the monograph of Clitoria. Across all three subgenera, Fantz retains 58 species as valid, with numerous lower classifications of varieties and subspecies (Fantz, 1977).

Clitoria ternatea is the holotype of Clitoria subgenus Clitoria, and represents the archetypical Clitoria. The etymology of the specific name is postulated to be from the island of Ternate in the Indonesian archipelago because it is from specimens from that location that Linnaeus produced the specific description. Ternate is not in the Indian Ocean but is instead in the Molucca Sea and in eastern Indonesia, lending ambiguity to the native range of the species. The distribution of all other taxa in subgenus Clitoria is restricted to Southern and Eastern Africa, India, Madagascar, and other islands of the Western Indian Ocean (Figure 3). The exact geographic origin of C. ternatea is thus difficult to determine, but we may infer from the center of diversity for subgenus Clitoria, that C. ternatea arose in or around the Indian Ocean and not the Pacific Ocean or South China Sea where it has been in use as a food coloring historically (Fantz, 1977; Staples, 1992). It is also entirely possible that the taxon we know as $C$. ternatea is an ancient hybrid of one or more members of the subgenus Clitoria that had subsequently been introduced to Southeast Asia. Testing of this synthetic origin hypothesis would require large scale genetics work on $C$. ternatea and related taxa like Clitoria biflora, C. kaessneri, C. lasciva, and C. heterophylla. Regardless of the specific geographical origin and evolutionary history of C. ternatea, the present day distribution of naturalized 


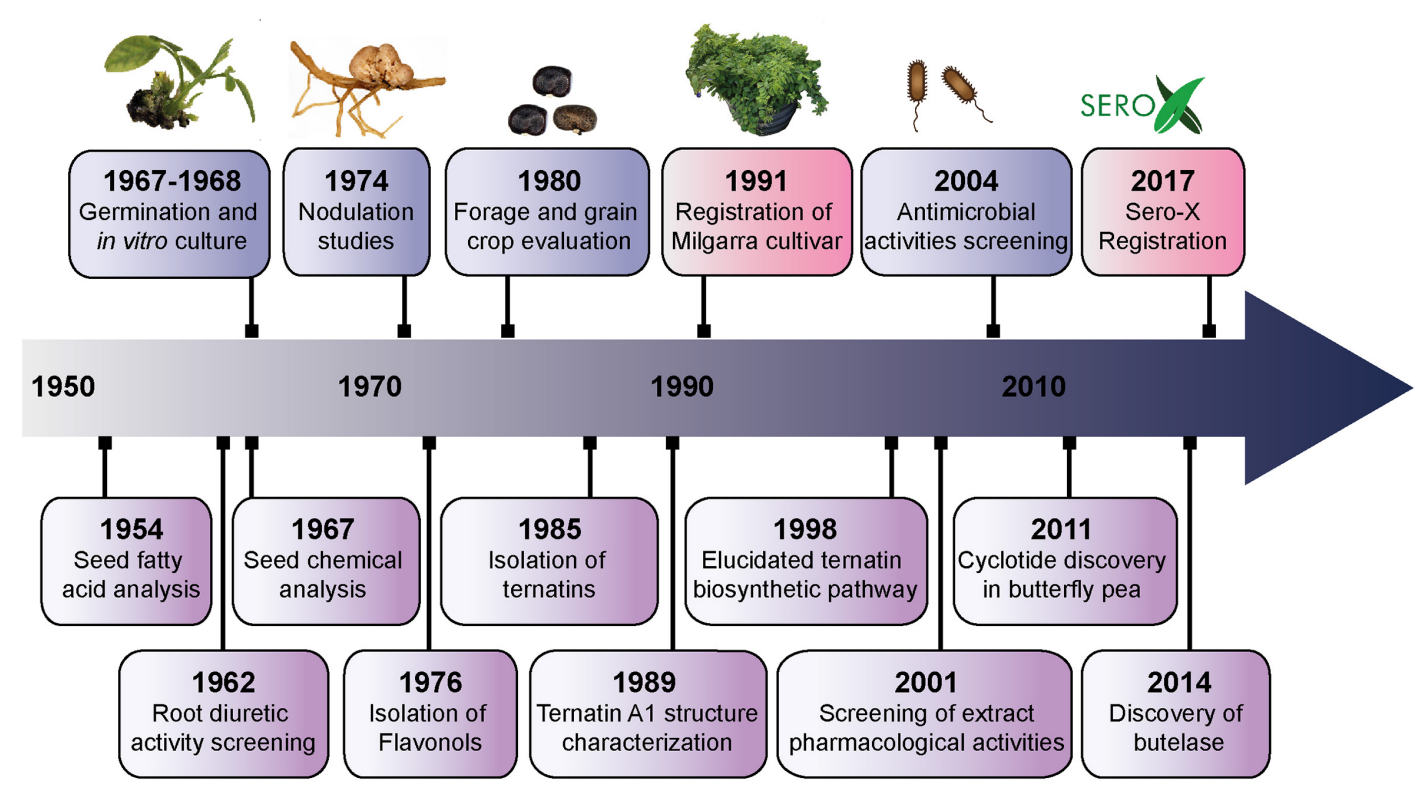

FIGURE 1 | Timeline of the key studies and milestones on Clitoria ternatea research from the 1950s to the present. The biological (blue) and biochemical (purple) studies pursued from the 1950s to early 1970s characterized the properties of roots and seeds. Toward the end of the 1970s, researchers began to isolate and characterize the phytochemical compounds from C. ternatea. Ternatins, the anthocyanins that render C. ternatea its vivid blue color, were first isolated in 1985; and the structure of the largest of the ternatins, ternatin A1, was characterized in 1989. Further isolation and characterization of the ternatins in C. ternatea led to the elucidation of the ternatin biosynthetic pathway in 1998. Parallel to the studies that characterized the phytochemical composition of $C$. ternatea, were agricultural studies that evaluated C. ternatea as a forage and fodder crop. A series of field studies in Queensland, Australia lead the development and eventual release of the C. ternatea Milgarra cultivar in 1991. From 2001 to the present, studies have been determining the pharmacological activities and biological activities of $C$. ternatea extracts. In 2011, cyclotides, the circular insecticidal molecules which can also be used as scaffolds for peptide-based therapeutics, were discovered in C. ternatea. While cyclotides had previously been characterized in other angiosperm species, C. ternatea is to date, the only legume that is known to produce them. In 2014 , butelase-1, the ligase that facilitates cyclization in $C$. ternatea cyclotides, was discovered and characterized. Cyclotides and the auxiliary enzymes, have applications both in modern medicine and agriculture. In 2017 , Sero- $X{ }^{\circledR}$ an eco-friendly insecticide made from C. ternatea extracts was registered for commercial use in Australia.

populations of $C$. ternatea is pantropical, as facilitated by key characteristics of the species: tolerance to drought conditions, non-reliance on specific pollinators because of self-pollination, and nitrogen fixation capability (Cobley, 1956; Staples, 1992; Conway et al., 2001). It is also possible to cultivate and maintain populations in subtropical regions (ex. Wee Waa NSW, located at $-30.2,149.433333)$.

The habitat of C. ternatea is open mesic forest or shrub land (personal observations of authors and records in the Australasian Virtual Herbrarium ${ }^{2}$ ). In Australia, the authors note that populations of $C$. ternatea occur in tropical regions in open areas where sunlight is plentiful due to a sparse canopy and in areas near where fresh water would collect such as the border of wetlands, small gullies, or at the base of rocky hillsides. When present, the plants are often vigorous and smother other vegetation.

\section{Growth and Propagation}

Germination and establishment of $C$. ternatea is most favorable when the temperature is between $24-32^{\circ} \mathrm{C}$, and when seeds are sown in moist soil at $2.5-5 \mathrm{~cm}$ deep and $20-30 \mathrm{~cm}$ apart (McDonald, 2002; Conway, 2005). Although C. ternatea can withstand arid conditions (Cobley, 1956), the plant grows best

${ }^{2}$ https://avh.chah.org.au/ with ample moisture and rainfall $(650-1250 \mathrm{~mm})$ and when the temperature reaches $27^{\circ} \mathrm{C}$ or higher (Conway and Collins, 2005). Like most tropical legumes, $C$. ternatea is susceptible to frost damage (Conway and Collins, 2005). However, it can retain its leaves for as long as 7 days, and its woody parts typically recover (Conway and Collins, 2005).

Despite its hardy features, one of the impediments in propagating C. ternatea is its low seed germination rate. This problem has long been recognized as evident in a study conducted in 1967 (Mullick and Chatterji, 1967). The study showed that freshly harvested $C$. ternatea would not imbibe water and germinate (Mullick and Chatterji, 1967). On the other hand, storing the seeds for another 6 months promoted germination in 15-20\% of the seeds (Mullick and Chatterji, 1967). Chemical scarification by means of soaking the seeds in boiling water or sulfuric acid was also found to promote C. ternatea seed germination (Cruz et al., 1995) where soaking the seeds in concentrated sulfuric acid for at least $10 \mathrm{~min}$ resulted in a reported 100\% seed germination rate (Patel et al., 2016).

In vitro propagation can circumvent the unreliably low seed germination rate in $C$. ternatea. It can also be an alternative method for conserving and mass propagating C. ternatea lines with superior qualities. In 1968, a study determined the effects of adding ascochitine on the growth of $C$. ternatea embryos (Lakshmanan and Padmanabhan, 1968). That study reported that 
TABLE 1 | Milestones in Clitoria ternatea studies.

\begin{tabular}{|c|c|c|}
\hline Years & Milestones & References \\
\hline 1954 & $\begin{array}{l}\text { Seed fatty acid composition } \\
\text { analyzed }\end{array}$ & Grindley et al., 1954 \\
\hline 1962 & $\begin{array}{l}\text { Root diuretic properties } \\
\text { screened }\end{array}$ & Piala et al., 1962 \\
\hline 1967 & $\begin{array}{l}\text { Phytochemical composition of } \\
\text { seeds analysis }\end{array}$ & $\begin{array}{l}\text { Kulshreshtha and Khare, } \\
1967\end{array}$ \\
\hline $1967-1968$ & $\begin{array}{l}\text { Germination studies and in vitro } \\
\text { propagation }\end{array}$ & Mullick and Chatterji, 1967 \\
\hline 1974 & $\begin{array}{l}\text { Nodulation pattern } \\
\text { characterized }\end{array}$ & Oblisami, 1974 \\
\hline 1976 & $\begin{array}{l}\text { Kaempferol-glycosides in } \\
\text { leaves isolated }\end{array}$ & Morita et al., 1976 \\
\hline $1980-1990$ & $\begin{array}{l}\text { Forage and grain crop } \\
\text { properties evaluated }\end{array}$ & $\begin{array}{l}\text { Reid and Sinclair, 1980; Barro } \\
\text { and Ribeiro, 1983; Hall, } 1985\end{array}$ \\
\hline 1985 & Ternatins isolated from flowers & Saito et al., 1985 \\
\hline 1989 & $\begin{array}{l}\text { Structure of Ternatin A1 } \\
\text { determined }\end{array}$ & Terahara et al., 1989a \\
\hline 1991 & $\begin{array}{l}\text { Milgarra cultivar registered in } \\
\text { Australia }\end{array}$ & Oram, 1992 \\
\hline 1998 & $\begin{array}{l}\text { Ternatin biosynthetic pathway } \\
\text { determined }\end{array}$ & Terahara et al., 1998 \\
\hline 2000 & $\begin{array}{l}\text { Pharmacological activities of } \\
\text { the extracts determined }\end{array}$ & Rai et al., 2001 \\
\hline 2004 & $\begin{array}{l}\text { Antimicrobial properties } \\
\text { characterized }\end{array}$ & Kelemu et al., 2004 \\
\hline 2011 & $\begin{array}{l}\text { Cyclotides in C. ternatea } \\
\text { discovered }\end{array}$ & Poth et al., 2011a,b \\
\hline 2014 & Butelase discovered & Nguyen et al., 2014 \\
\hline 2017 & Sero- $X^{\circledR}$ registered & Innovate Ag, $2018^{1}$ \\
\hline
\end{tabular}

${ }^{1}$ https://innovate-ag.com.au/.

$60 \%$ of the embryos produced callus in both the upper and lower hypocotyl when 5-10 ppm ascochitine was added to the culture media. Numerous studies have since been conducted from 1990 to 2016 to determine the optimal plant hormone concentrations, basal media types and explant types for C. ternatea in vitro propagation (Table 2 ).

With the optimal hormone concentrations supplemented in the basal medium, callus production was observed from mature C. ternatea embryos, leaf and root explants obtained from aseptic seedlings (Lakshmanan and Dhanalakshmi, 1990; Shahzad et al., 2007; Mohamed and Taha, 2011). In some instances, prolonged explant maintenance in the same callus induction medium led to embryoid production (Lakshmanan and Dhanalakshmi, 1990). Recently, a study described a protocol to produce encapsulated embryogenic callus from leaf explants using the optimal hormone concentrations and 3\% sodium alginate (Mahmad et al., 2016). The study reported that more than $50 \%$ of the encapsulated explants stored at $4^{\circ} \mathrm{C}$ for 90 days survived (Mahmad et al., 2016). Studies showed that shoots can be regenerated from callus (Shahzad et al., 2007; Mahmad et al., 2016). Alternatively, shoots can also be induced and proliferated directly from different explant types such as isolated shoot buds (Lakshmanan and Dhanalakshmi, 1990), axillary buds (Mhaskar et al., 2011), shoot tips (Pandeya et al., 2010), leaf (Mohamed and Taha,
2011), and root (Shahzad et al., 2007) from aseptic seedlings, cotyledonary nodes (Pandeya et al., 2010; Mukhtar et al., 2012) and nodal explants (Rout, 2005; Pandeya et al., 2010; Ismail et al., 2012; Mukhtar et al., 2012). These in vitro grown C. ternatea shoots when subsequently placed in a medium supplemented with the optimal auxin concentrations produced roots in vitro (Lakshmanan and Dhanalakshmi, 1990; Rout, 2005; Shahzad et al., 2007; Mhaskar et al., 2011; Mohamed and Taha, 2011; Ismail et al., 2012; Mukhtar et al., 2012). Nevertheless, ex vitro root production was observed when elongated shoots were soaked in a concentrated auxin solution (Pandeya et al., 2010).

Moreover, a study has described propagation of C. ternatea via hairy root cultures (Swain et al., 2012b). Using the wildtype Agrobacterium rhizogenes strain A4T with the optimal culture conditions, a transformation frequency of as high as $85.8 \%$ was observed (Swain et al., 2012b). Compared to roots obtained from outdoor grown plants, C. ternatea hairy root cultures produced fourfold the amount of taraxerol, an anticancer triterpenoid compound that is naturally produced in C. ternatea roots (Swain et al., 2012a).

\section{HISTORICAL AND CURRENT APPLICATIONS}

\section{Agriculture Fodder and Forage Crop}

Clitoria ternatea has long been cultivated as a forage crop (Cobley, 1956), with yields reaching 17-29 tons/ha of palatable hay for cattle (Barro and Ribeiro, 1983; Abdelhamid and Gabr, 1993). This yield is on par with the established forage crop, alfalfa (Medicago sativa), and can potentially replace it in warm areas with low rainfall (Barro and Ribeiro, 1983). In Australia, C. ternatea has been cultivated predominantly in Queensland, due to its adaptability in the arid regions and persistence in heavy-textured farm lands (Hall, 1985). In 1991, the Queensland Department of Primary Industries, released the C. ternatea cv. 'Milgarra' mainly for grazing purposes (Oram, 1992). Milgarra is a composite of 21 introduced and naturalized C. ternatea lines that were grown for over three generations (Oram, 1992). As it is a composite cultivar, phenotypic variations are commonly observed in the field (Conway and Doughton, 2005).

Timing of harvest has been demonstrated to be important for maximizing dry matter content and digestibility of $C$. ternatea hay, with 45 days shown to be optimal (Mahala et al., 2012). Further increases in dry matter content have been reported if C. ternatea is pruned every 42 days at $20 \mathrm{~cm}$ (Colina et al., 1997), with dry matter yields of $1122 \mathrm{~kg} / \mathrm{ha}$ reported. Compared to other legumes, animal feeds prepared from C. ternatea have consistently lower acid detergent fiber content. This low amount of acid detergent fiber increases energy density of the feed, and retains a high nitrogen content (Jones et al., 2000). Thus, feeds made from this plant have favorable nutritional characteristics compared to other legume forages. C. ternatea is also a great source of carotenoids with the carotenoid content of a 6-month old hay reaching 600 mg/kg dry matter (Barro and Ribeiro, 1983). 


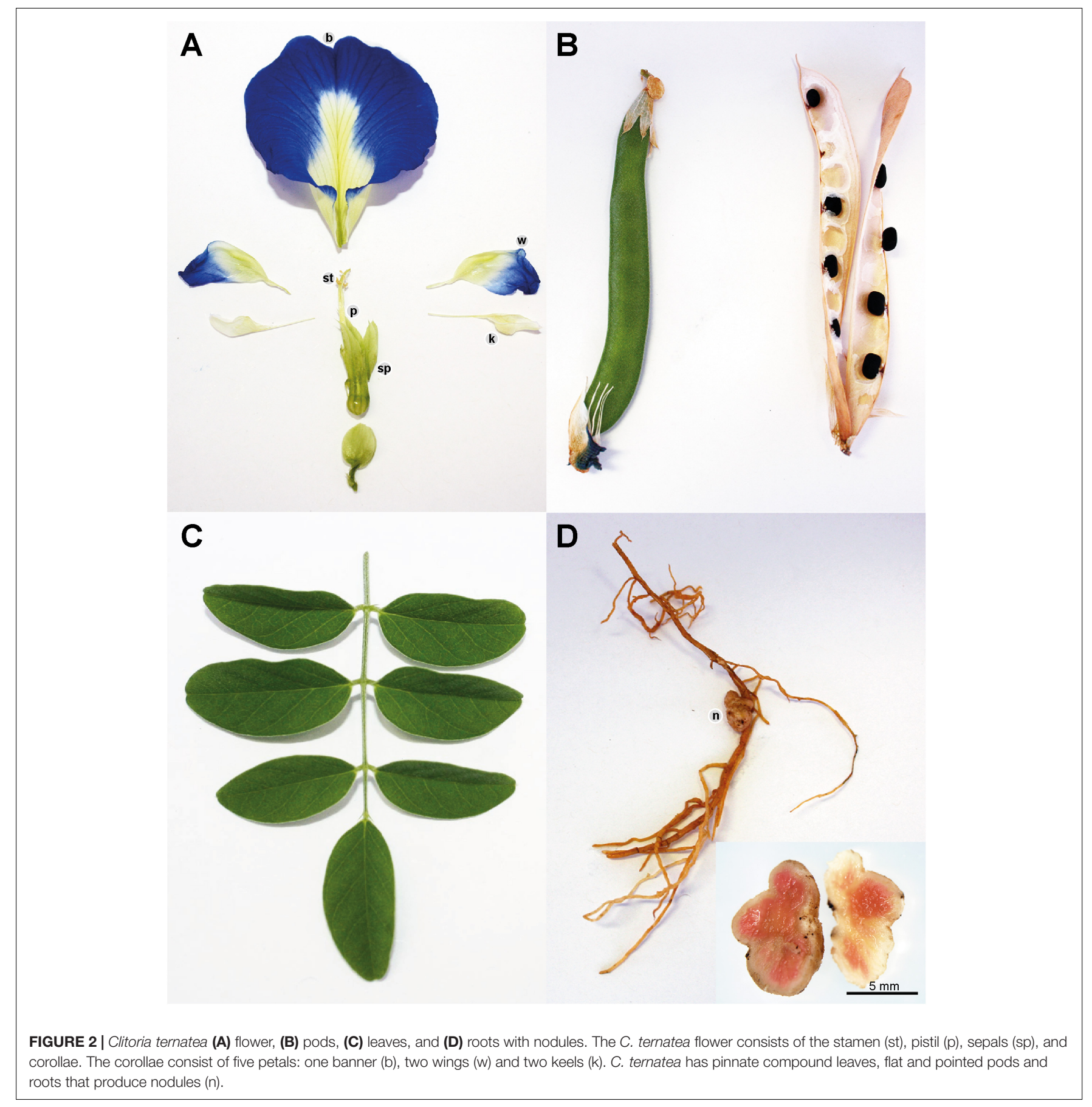

\section{Nitrogen Fixation and Improvement of Soil Nutrient Content}

Clitoria ternatea roots produce large round nodules (Cobley, 1956) (Figure 2D) known to house nitrogen-fixing bacteria, making the plant ideal for use in a crop rotation system. As early as the 1970s, studies were conducted to assess the nitrogen-fixing capacity of C. ternatea (Oblisami, 1974; De Souza et al., 1996). Nodulation was shown to be more favorably induced with a soil moisture content of around $25-45 \%$ with a light duration of $11-14 \mathrm{~h}$ and an intensity of $11-17 \mathrm{~W} / \mathrm{m}^{2}$
(Habish and Mahdi, 1983). Supplementing the soil with sulfur was also demonstrated as beneficial for nodule formation (Zaroug and Munns, 1980a). Several studies have reported the benefits of C. ternatea to soil health (De Souza et al., 1996; Dwivedi and Kumar, 2001; Kamh et al., 2002; Alderete-Chavez et al., 2011). Field trials conducted in Mexico reported that at 180 days post planting of C. ternatea, the organic matter, N, P, and K content of the soil all increased significantly (Alderete-Chavez et al., 2011). A similar study conducted in India reported that intercropping C. ternatea with the fodder crop Setaria sphacelata enriched the 


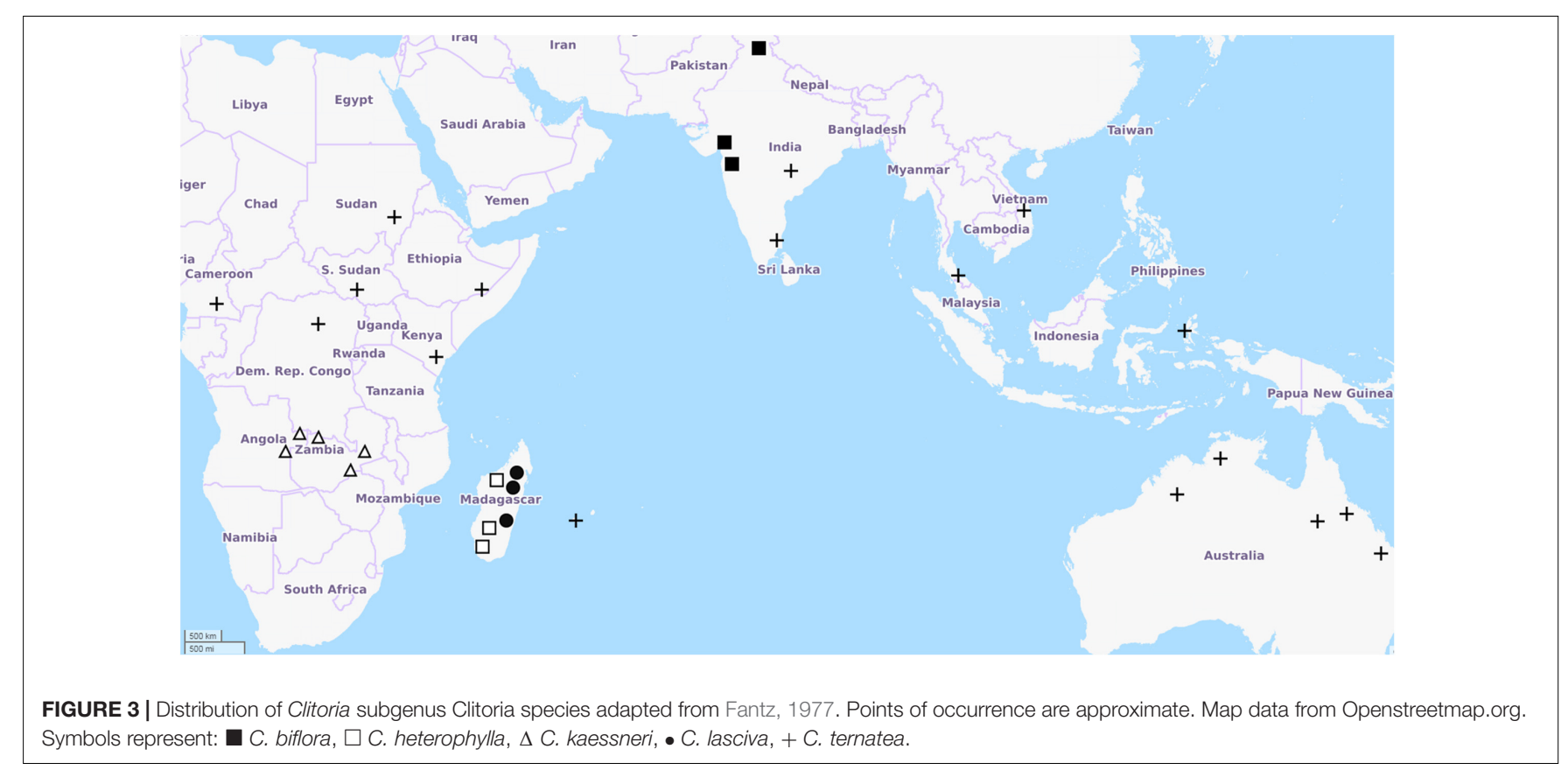

$\mathrm{N}$ content of the soil to an estimated $39.8 \mathrm{~kg} / \mathrm{ha}$ (Dwivedi and Kumar, 2001). The results suggest that intercropping $C$. ternatea may potentially lead to a shorter fallow period requirement (Njunie et al., 2004).

When considering crop rotations, it is important to determine the cross nodulation capacity of nitrogen fixing Rhizobium species. One study showed that the Rhizobium species isolated from C. ternatea, cow pea and soybean are more compatible to each other than other legume species (Oblisami, 1974), while cross inoculation of Rhizobium sp. from C. ternatea and the legume species, Phaseolus vulgaris, $M$. sativa, and Pisum sativum, produced no nodules (Oblisami, 1974). These studies provide insights as to which legume species, when planted together with C. ternatea, are more likely to form nodules and thereby yield the most soil benefits. Another early study showed that the symbiotic efficiencies measured, based on C. ternatea dry matter yield, varied depending on the Rhizobium sp. strains tested (Zaroug and Munns, 1980b). A more recent study reported the isolation and identification of 11 rhizobial strains from C. ternatea grown in Thailand (Duangkhet et al., 2018). The 16s rDNA phylogenetic analysis revealed that ten of these isolates were Bradyrhizobium elkanii strains while the remaining isolate was a Bradyrhizobium japonicum strain. These C. ternatea B. elkanii strains were shown to promote better plant growth and induce higher nitrogenfixing capacity than $B$. elkanii strains isolated from soybean (Duangkhet et al., 2018).

\section{Medicine}

The popular use of $C$. ternatea in traditional medicine has stimulated researchers to elucidate the pharmacological activities of extracts obtained from various $C$. ternatea tissues. Numerous animal studies have reported that the extracts exhibit diuretic, nootropic, antiasthmatic, anti-inflammatory, analgesic, antipyretic, antidiabetic, antilipidemic, anti-arthritic, antioxidant, and wound healing properties. The results of the animal and in in vitro studies are summarized in Tables 3 and 4, respectively. Although these combined studies claim that C. ternatea extracts showcase a diverse range of pharmacological properties, many of these studies are preliminary and require more thorough investigation. In many instances the authors have attributed the extract activities to the presence of flavonols and anthocyanins, however, attempts to isolate and test individual components are limited. Indeed several components in C. ternatea extracts could be acting synergistically. For instance, cyclotides which have been reported to have immunosuppressive properties may contribute (Gründemann et al., 2012, 2013; Thell et al., 2016), as could the abundance of delphinidins (Sogo et al., 2015; Tani et al., 2017; Harada et al., 2018).

\section{Nootropic Activity}

Several studies have reported improvement in cognitive performance when $C$. ternatea extracts were administered to experimental animals (Taranalli and Cheeramkuzhy, 2000; Rai et al., 2001; Jain et al., 2003). In one study, rats orally dosed with ethanolic extracts derived from $C$. ternatea roots or aerial tissues were shown to attenuate electric shock-induced amnesia better than the controls (Taranalli and Cheeramkuzhy, 2000). In a separate study, 7-day old neonatal rats orally dosed with aqueous $C$. ternatea root extract also showed improved memory retention and enhanced spatial learning performance $48 \mathrm{~h}$ and 30 days post treatment (Rai et al., 2001). Further investigations revealed that the brains of treated rats contained a significantly higher acetylcholine content than the controls (Taranalli and Cheeramkuzhy, 2000; Rai et al., 2002). A more recent study of the effects of C. ternatea leaf extracts on diabetic-induced cognitive decline showed that the acetylcholinesterase activity, total nitric oxide levels and lipid peroxide levels all significantly 
TABLE 2 | Summary of published Clitoria ternatea in vitro propagation studies.

\begin{tabular}{|c|c|c|c|c|}
\hline Hormone concentrations & $\begin{array}{l}\text { Basal } \\
\text { medium }\end{array}$ & Explants used & Results & References \\
\hline- & MS & Mature embryo & Callus on seedling root & Lakshmanan and Dhanalakshmi, 1990 \\
\hline $0.1 \mathrm{mg} / \mathrm{L} \mathrm{KN}$ & MS & Mature embryo & $\begin{array}{l}\text { Callus on seedling } \\
\text { lateral root }\end{array}$ & Lakshmanan and Dhanalakshmi, 1990 \\
\hline $0.5 \mathrm{mg} / \mathrm{L} \mathrm{KN}$ & MS & Mature embryo & $\begin{array}{l}\text { Callus on seedling root } \\
\text { and hypocotyl; } \\
\text { embryogenesis }\end{array}$ & Lakshmanan and Dhanalakshmi, 1990 \\
\hline $0.5 \mathrm{mg} / \mathrm{L} \mathrm{KN}+0.5 \mathrm{mg} / \mathrm{L} \mathrm{IAA}$ & MS & Mature embryo & $\begin{array}{l}\text { Callus on seedling root; } \\
\text { embryogenesis }\end{array}$ & Lakshmanan and Dhanalakshmi, 1990 \\
\hline $\begin{array}{l}1.12 \mathrm{mg} / \mathrm{L} \text { BAP }+2.2 \mathrm{or} \\
4.4 \mathrm{mg} / \mathrm{L} 2,4-\mathrm{D}\end{array}$ & MS & Excised root segments from aseptic seedlings & Organogenic callus & Shahzad et al., 2007 \\
\hline $2.0 \mathrm{mg} / \mathrm{L} \mathrm{BAP}+1.0 \mathrm{mg} / \mathrm{L} \mathrm{NAA}$ & $\mathrm{DKW}$ & Leaf explants from aseptic seedlings & Callus formation & Mohamed and Taha, 2011 \\
\hline $\begin{array}{l}1.0 \mathrm{mg} / \mathrm{L} \mathrm{NAA}+0.5 \mathrm{mg} / \mathrm{L} \\
\mathrm{BAP}+40 \mathrm{mg} / \mathrm{L} 2 \mathrm{iP}\end{array}$ & MS & $\begin{array}{l}\text { Aseptic leaf explants encapsulated using } 3 \% \\
\text { sodium alginate }\end{array}$ & Callus formation & Mahmad et al., 2016 \\
\hline $\begin{array}{l}0.56-2.25 \mathrm{mg} / \mathrm{L} \\
\mathrm{BAP}+0.37 \mathrm{mg} / \mathrm{L} \mathrm{NAA}\end{array}$ & MS & Calli derived from excised root segments & Shoot proliferation & Shahzad et al., 2007 \\
\hline- & $1 / 2 \mathrm{MS}$ & $\begin{array}{l}\text { Isolated shoot buds }(0.2-0.5 \mathrm{~cm} \text { in length) from } \\
\text { mature embryo }\end{array}$ & Shoot proliferation & Lakshmanan and Dhanalakshmi, 1990 \\
\hline $0.1-0.5 \mathrm{mg} / \mathrm{L}$ BAP & MS & $\begin{array}{l}\text { Isolated shoot buds }(0.2-0.5 \mathrm{~cm} \text { in length) from } \\
\text { mature embryo }\end{array}$ & Shoot proliferation & Lakshmanan and Dhanalakshmi, 1990 \\
\hline $\begin{array}{l}2.5 \mathrm{mg} / \mathrm{L} \mathrm{BAP}+0.25 \mathrm{mg} / \mathrm{L} \\
\mathrm{NAA}\end{array}$ & MS & Axillary buds & Shoot proliferation & Mhaskar et al., 2011 \\
\hline $2 \mathrm{mg} / \mathrm{L}$ BAP + $0.25 \mathrm{mg} / \mathrm{L} \mathrm{NAA}$ & $\begin{array}{l}\text { Semisolid } \\
\text { MS }\end{array}$ & Nodal explants & Shoot proliferation & Rout, 2005 \\
\hline $1.12 \mathrm{mg} / \mathrm{L}$ BAP & MS & Nodal explants & Shoot proliferation & Ismail et al., 2012 \\
\hline $2.0 \mathrm{mg} / \mathrm{L}$ BAP & MS & Shoot tip, node, cotyledonary node explants & Shoot proliferation & Pandeya et al., 2010 \\
\hline $0.5 \mathrm{mg} / \mathrm{L} \mathrm{GA}$ & MS & Shoot tip, node, cotyledonary node explants & Shoot elongation & Pandeya et al., 2010 \\
\hline $1.0 \mathrm{mg} / \mathrm{L}$ BAP & DKW & Leaf explants from aseptic seedlings & Shoot proliferation & Mohamed and Taha, 2011 \\
\hline $\begin{array}{l}4.5 \mathrm{mg} / \mathrm{L} \mathrm{BAP}+0.37 \mathrm{mg} / \mathrm{L} \\
\mathrm{NAA}\end{array}$ & MS & Excised root segments from aseptic seedlings & Shoot proliferation & Shahzad et al., 2007 \\
\hline 0.02 mg/L TDZ; 0.2 mg/L TDZ & MS & Cotyledonary node; nodal explants & Shoot proliferation & Mukhtar et al., 2012 \\
\hline $0.1-0.5 \mathrm{mg} / \mathrm{L}$ IBA & MS & $\begin{array}{l}\text { Isolated shoots ( } 2.0-5.0 \mathrm{~cm} \text { in length) } \\
\text { proliferated from mature embryo }\end{array}$ & Rooting & Lakshmanan and Dhanalakshmi, 1990 \\
\hline $0.1-0.5 \mathrm{mg} / \mathrm{L}$ IAA & MS & $\begin{array}{l}\text { Isolated shoots ( } 2.0-5.0 \mathrm{~cm} \text { in length) } \\
\text { proliferated from mature embryo }\end{array}$ & Rooting & Lakshmanan and Dhanalakshmi, 1990 \\
\hline $0.25 \mathrm{mg} / \mathrm{L} \mathrm{NAA}$ & $\begin{array}{l}1 / 2 \mathrm{MS} \\
(2 \% \text { suc })\end{array}$ & Directly regenerated shoots from nodal explants & Rooting & Rout, 2005 \\
\hline $1.0 \mathrm{mg} / \mathrm{L} \mathrm{IBA}$ & $1 / 2 \mathrm{MS}$ & Shoots derived from organogenic calli & Rooting & Shahzad et al., 2007 \\
\hline $0.2-0.4 \mathrm{mg} / \mathrm{L}$ IBA & $1 / 2 \mathrm{MS}$ & $\begin{array}{l}\text { Directly regenerated elongated shoots from } \\
\text { nodal, cotyledonary nood and shoot tips }\end{array}$ & Rooting & Ismail et al., 2012; Mukhtar et al., 2012 \\
\hline $0.56 \mathrm{mg} / \mathrm{L} \mathrm{NAA}$ & MS & Directly regenerated shoots from axillary buds & Rooting & Mhaskar et al., 2011 \\
\hline $\begin{array}{l}\text { Dipping in } 250 \mathrm{mg} / \mathrm{L} \text { IBA for } \\
30 \mathrm{~min}\end{array}$ & Soilrite & Elongated shoots & Rooting (ex vitro) & Pandeya et al., 2010 \\
\hline $2.0 \mathrm{mg} / \mathrm{L} \mathrm{NAA}$ & DKW & Leaf explants from aseptic seedlings & Rooting & Mohamed and Taha, 2011 \\
\hline
\end{tabular}

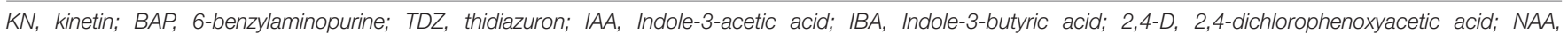

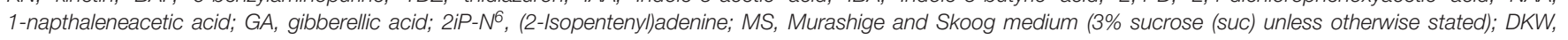
Driver Kuniyuki Walnut medium (3\% suc).

decreased upon treatment, whilst the catalase, superoxide dismutase and glutathione levels all significantly increased (Talpate et al., 2014). Another recent study showed that rats fed for 60 days with "medhya rasayana," a mixture of crushed C. ternatea and jaggery (1:1), exhibited significant reduction in autophagy in the brain (Raghu et al., 2017). The treated and the control rats also differentially expressed genes implicated in autophagy regulation, nucleotide excision repair, homologous recombination, etc. The study suggested that $C$. ternatea protects the brain by affecting the autophagy directed pathway (Raghu et al., 2017).

Anti-inflammatory, Analgesic, and Antipyretic Activity Extracts of $C$. ternatea roots and leaves have been reported to demonstrate anti-inflammatory, analgesic, and antipyretic activities (Devi et al., 2003; Parimaladevi et al., 2004; Bhatia et al., 2014; Singh et al., 2018). Oral administration of the methanolic root extracts and ethanolic floral extracts of $C$. ternatea was 


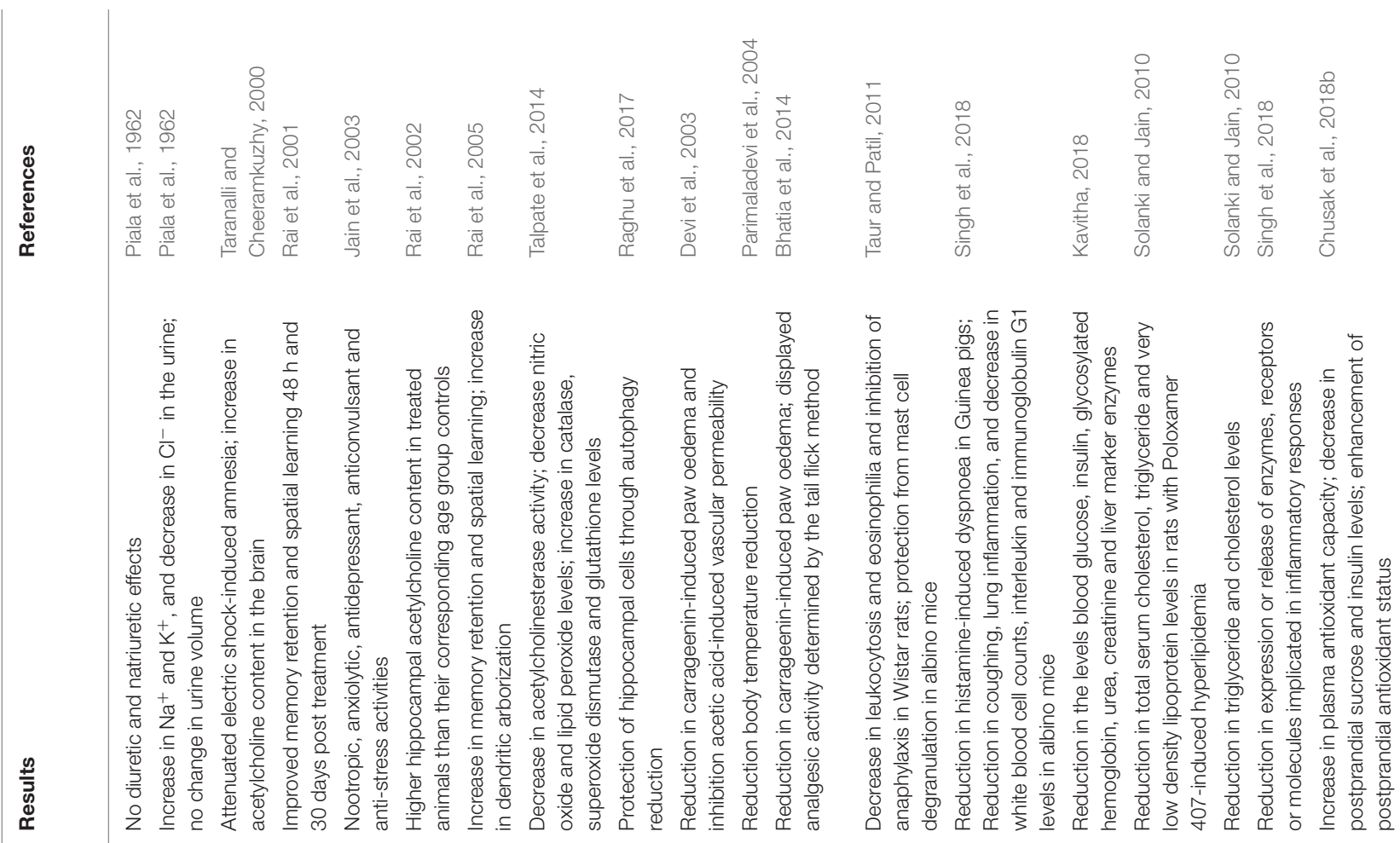

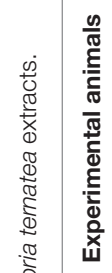

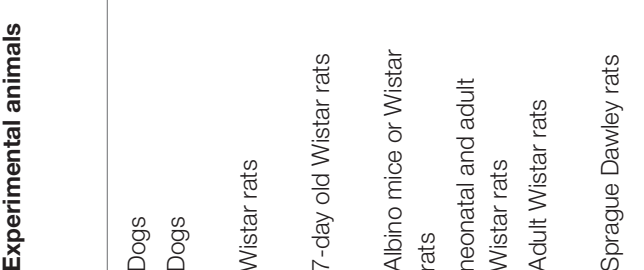

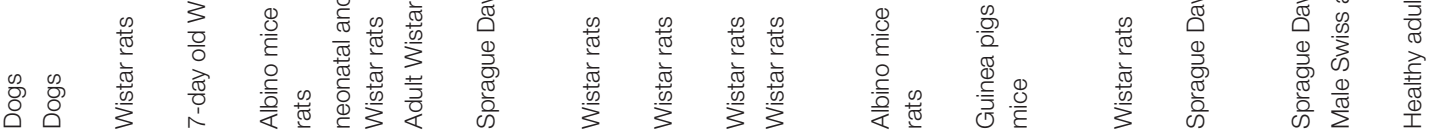

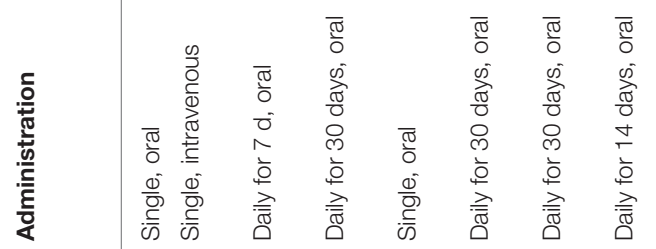

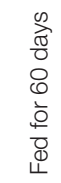

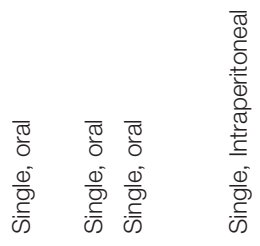

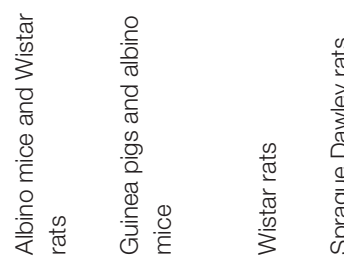

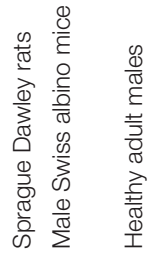

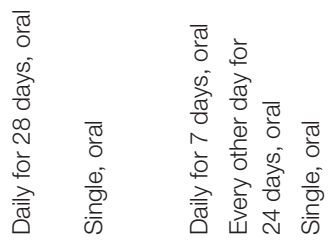

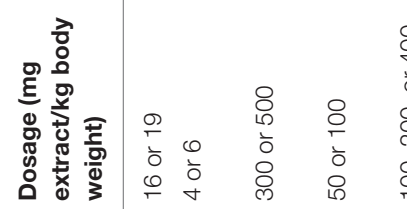

$\frac{8}{\stackrel{8}{+}}$

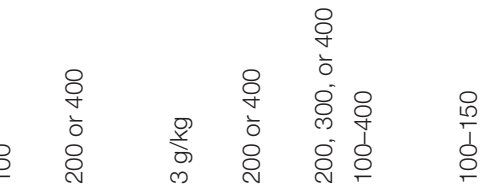

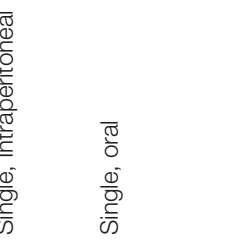

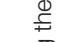

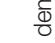

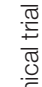

呇

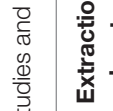

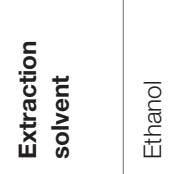

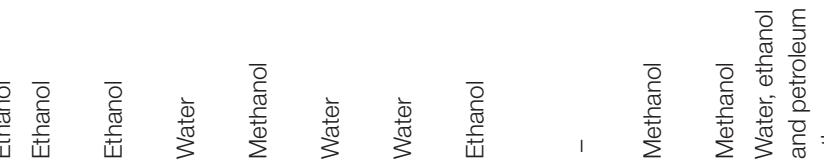
1

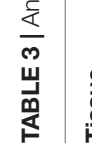

$\frac{+}{0}$
$\frac{\pi}{2}$
$\frac{0}{0}$
$\frac{0}{3}$

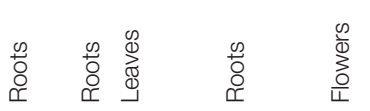


TABLE 4 | In vitro studies demonstrating the pharmacological properties of Clitoria ternatea extract.

\begin{tabular}{|c|c|c|c|c|}
\hline Extract & Concentration & In vitro assay & Results & References \\
\hline $\begin{array}{l}\text { Ethanolic floral } \\
\text { extract }\end{array}$ & $2.5-10 \mathrm{mg} / \mathrm{mL}$ & $\begin{array}{l}\text { Extract addition to isolated } \\
\text { adult goat tracheal tissue and } \\
\text { guinea pig ileum dosed with } \\
\text { histamine }\end{array}$ & Inhibition of histamine-induced contraction & Singh et al., 2018 \\
\hline $\begin{array}{l}\text { Methanolic leaf } \\
\text { extract }\end{array}$ & $\begin{array}{l}\text { Six } 2 \text {-fold dilution of } \\
50 \mu \mathrm{g} / \mathrm{ml}\end{array}$ & Hyaluronidase inhibition assay & Significant inhibition; $\mathrm{IC}_{50}=18.08 \pm 0.46 \mu \mathrm{g} / \mathrm{ml}$ & Maity et al., 2012 \\
\hline $\begin{array}{l}\text { Methanolic leaf } \\
\text { extract }\end{array}$ & $\begin{array}{l}\text { Six } 2 \text {-fold dilution of } \\
50 \mu \mathrm{g} / \mathrm{ml}\end{array}$ & $\begin{array}{l}\text { Matrix metalloproteinase-1 } \\
\text { inhibition assay (MMP-1) }\end{array}$ & Significant inhibition of MMP-1 & Maity et al., 2012 \\
\hline $\begin{array}{l}\text { Aqueous floral } \\
\text { extract }\end{array}$ & $400 \mu \mathrm{g} / \mathrm{mL}$ & $\begin{array}{l}\text { Hemolytic and oxidation assays } \\
\text { on canine erythrocytes }\end{array}$ & $\begin{array}{l}60 \% \text { erythrocyte hemolysis protection after } 6 \mathrm{~h} \text {; } \\
\text { decrease in lipid peroxidation and protein oxidation and } \\
\text { increase in glutathione levels }\end{array}$ & Phrueksanan et al., 2014 \\
\hline $\begin{array}{l}\text { Aqueous floral } \\
\text { extract }\end{array}$ & $\begin{array}{l}1 \text { and } 2 \%(\mathrm{w} / \mathrm{v}) \\
\text { extract }\end{array}$ & Porcine $\alpha$-amylase assay & $\begin{array}{l}\text { Significant } \alpha \text {-amylase inhibition, reduction in glucose } \\
\text { release, hydrolysis index and glycemic index }\end{array}$ & Chusak et al., 2018a \\
\hline
\end{tabular}

reported to significantly inhibit carrageenin-induced rat paw oedema and acetic acid-induced vascular permeability in rats (Devi et al., 2003; Singh et al., 2018). Results with an oral dosage of $400 \mathrm{mg}$ extract per $\mathrm{kg}$ body weight were on par with a $20 \mathrm{mg} / \mathrm{kg}$ oral dosage of diclofenac sodium (Devi et al., 2003), a non-steroidal anti-inflammatory drug. In an antipyretic study, oral administration of $C$. ternatea methanolic root extracts significantly reduced the body temperature of Wistar rats that had yeast-induced elevated body temperature (Parimaladevi et al., 2004). This antipyretic activity of the extract was found to be comparable to paracetamol (Parimaladevi et al., 2004). More recently, C. ternatea leaf extracts have been implicated for use as an analgesic (Bhatia et al., 2014). In this study the established rat tail flick pain assay was used to determine the effects of pretreatment with both ethanolic and petroleum $C$. ternatea extracts. A positive analgesic effect of $C$. ternatea leaf extracts was reported, comparable to diclofenac sodium $(10 \mathrm{mg} / \mathrm{kg}) 1 \mathrm{~h}$ post treatment (Bhatia et al., 2014).

\section{Antidiabetic Activity}

Recently, C. ternatea leaf extracts have shown potential for use as an antidiabetic (Chusak et al., 2018b; Kavitha, 2018). Wistar rats orally dosed with $400 \mathrm{mg}$ C. ternatea ethanolic leaf extract per $\mathrm{kg}$ of body weight per day for 28 days, had significantly lower levels of blood glucose, insulin, glycosylated hemoglobin, urea and creatinine than the diabetic control. Furthermore, the levels of liver enzymes (serum glutamate oxalate transaminase, serum glutamate pyruvate transaminase, lactate dehydrogenase, and alkaline phosphatase) in treated rats were lower than the diabetic control rats and were comparable to the normal control rats (Kavitha, 2018). More recent studies have focused on the effects of $C$. ternatea extracts on the glycemic response and antioxidant capacity in humans (Chusak et al., 2018b). A small scale clinical trial involving 15 healthy males revealed that when either 1 or $2 \mathrm{~g}$ of C. ternatea extract was ingested together with $50 \mathrm{~g}$ sucrose the resulting plasma glucose and insulin levels were suppressed (Chusak et al., 2018b). Furthermore the postprandial plasma antioxidant capacities of the subjects were also enhanced upon extract consumption.

\section{Antioxidant Activity}

The antioxidant properties of C. ternatea extracts are well documented (Phrueksanan et al., 2014; Sushma et al., 2015). One study demonstrated that $C$. ternatea extracts could protect canine erythrocytes from hemolysis and oxidative damage induced by 2,2'-azobis-2-methyl-propanimidamide dihydrochloride (AAPH) (Phrueksanan et al., 2014). Compared to the AAPH control, erythrocytes treated with $400 \mu \mathrm{g} / \mathrm{mL}$ of the C. ternatea extract had significantly lower levels of AAPH-induced lipid peroxidation and protein oxidation, and significantly higher levels of glutathione (Phrueksanan et al., 2014). In another study the antioxidant properties within a C. ternatea extract facilitated the production of magnesium oxide nanoparticles, materials which are increasingly being utilized for biomedical applications (Sushma et al., 2015).

\section{Pesticidal Activities}

The anthelmintic and insecticidal activities, and the antimicrobial activities of $C$. ternatea extracts and several isolated protein and peptide components are summarized in Tables 5 and $\mathbf{6}$, respectively. These biological activities presumably evolved for host-defense purposes but can have potential applications both in agriculture and medicine. Further details on these activities are described in the following sections.

\section{Anthelmintic Activity}

The anthelmintic properties of C. ternatea have been reported in several studies (Hasan and Jain, 1985; Khadatkar et al., 2008; Salhan et al., 2011; Kumari and Devi, 2013; Gilding et al., 2015) (Table 5). Characterization of 27 homozygous C. ternatea lines showed that individual lines displayed different degrees of resistance against the parasitic root-knot nematode, Meloidogyne incognita (Hasan and Jain, 1985). The methanolic extract of C. ternatea was also found to inhibit $93 \%$ of $M$. incognita eggs from hatching (Kumari and Devi, 2013). In another study that utilized the model organism, Caenorhabditis elegans, C. ternatea extracts were found to effectively kill nematode larvae, with the root extracts showing greater lethality than the leaf extracts (Gilding et al., 2015). Two studies also reported C. ternatea activities against annelids (Khadatkar et al., 2008; 
TABLE 5 | Anthelmintic and insecticidal activities of Clitoria ternatea.

\begin{tabular}{|c|c|c|c|}
\hline Biological activity & Organism & Results & References \\
\hline \multirow[t]{5}{*}{ Anthelmintic } & Meloidogyne incognita & 27 C. ternatea lines displayed varying degrees of resistance & Hasan and Jain, 1985 \\
\hline & Meloidogyne incognita & Methanolic leaf extract inhibited 93\% of eggs from hatching & Kumari and Devi, 2013 \\
\hline & Caenorhabditis elegans & Significant toxicity of root extract on larvae & Gilding et al., 2015 \\
\hline & Pheretima posthuma & $\begin{array}{l}\text { Ethanolic root extract increased mortality rate and number or paralyzed worms at } \\
50 \mathrm{mg} / \mathrm{mL}\end{array}$ & Khadatkar et al., 2008 \\
\hline & Eisenia foetida & $\begin{array}{l}\text { Ethanolic and aqueous extract increased mortality and induced worm paralysis at } \\
100 \mathrm{mg} / \mathrm{mL}\end{array}$ & Salhan et al., 2011 \\
\hline \multirow[t]{4}{*}{ Insecticidal } & Acanthoscelides obtectus & $1 \% \mathrm{w} / \mathrm{w}$ finotin application resulted to $100 \%$ larval mortality & Kelemu et al., 2004 \\
\hline & Zabrotes subfasciatus & $5 \% \mathrm{w} / \mathrm{w}$ finotin application resulted to $100 \%$ larval mortality & Kelemu et al., 2004 \\
\hline & Helicoverpa armigera & $\begin{array}{l}\text { Cter M cyclotide retarded larval growth in a dose dependent manner; } 1 \mu \mathrm{mol} / \mathrm{g} \text { diet } \\
\text { induced larval mortality }\end{array}$ & Poth et al., 2011a \\
\hline & Helicoverpa spp. & $\begin{array}{l}1-2 \% \text { v/v oil-based extract resulted in larval mortality and reduced oviposition and larval } \\
\text { feeding; detrimental effects against beneficial insects were not observed }\end{array}$ & Mensah et al., 2015 \\
\hline
\end{tabular}

TABLE 6 | Antimicrobial activities of Clitoria ternatea.

\begin{tabular}{|c|c|c|c|}
\hline Biological activity & Organism & Extract/component & References \\
\hline \multirow[t]{12}{*}{ Antibacterial } & Bacillus cereus & Ethanolic and aqueous leaf and callus extract & Shahid et al., 2009 \\
\hline & Bacillus subtilis & Ethanolic and aqueous leaf and callus extract & Shahid et al., 2009 \\
\hline & Enterococcus faecalis & Ethanolic leaf and callus extract & Shahid et al., 2009 \\
\hline & Escherichia coli & Cliotides T1, T4, T7, T15, T16, T19, and T20 & Nguyen et al., 2011, 2016b \\
\hline & Klebsiella pneumoniae & Cliotides T1 and T4 & Nguyen et al., 2011, 2016c \\
\hline & Micrococcus luteus & $14.3 \mathrm{kDa}$ seed protein & Ajesh and Sreejith, 2014 \\
\hline & Pseudomonas aeruginosa & Cliotides T1 and T4 & Nguyen et al., 2011, 2016b \\
\hline & Staphylococcus aureus & $\begin{array}{l}\text { Ethanolic leaf and callus extract; ultrasound-assisted } \\
\text { aqueous leaf and petal extract }\end{array}$ & Shahid et al., 2009; Anthika et al., 2015 \\
\hline & Staphylococcus epidermidis & Ethanolic leaf and callus extract & Shahid et al., 2009 \\
\hline & Streptococcus pyogenes & Ethanolic leaf and callus extract, aqueous leaf extract & Shahid et al., 2009 \\
\hline & Streptococcus viridans & Ethanolic leaf and callus extract & Shahid et al., 2009 \\
\hline & Xanthomonas axonopodis & Finotin & Kelemu et al., 2004 \\
\hline \multirow[t]{21}{*}{ Antifungal } & Alternaria sp. & $14.3 \mathrm{kDa}$ seed protein & Ajesh and Sreejith, 2014 \\
\hline & Aspergillus flavus & $14.3 \mathrm{kDa}$ seed protein & Ajesh and Sreejith, 2014 \\
\hline & Aspergillus fumigatus & $14.3 \mathrm{kDa}$ seed protein & Ajesh and Sreejith, 2014 \\
\hline & Aspergillus niger & 14.3 kDa seed protein; methanolic leaf extract & Kamilla et al., 2009; Ajesh and Sreejith, 2014 \\
\hline & Bipolaris oryzae & Finotin & Kelemu et al., 2004 \\
\hline & Colletotrichum gloeosporioides & Finotin & Kelemu et al., 2004 \\
\hline & Colletotrichum lindemuthianum & Finotin & Kelemu et al., 2004 \\
\hline & Candida albicans & $14.3 \mathrm{kDa}$ seed protein & Ajesh and Sreejith, 2014 \\
\hline & Candida parapsilosis & 14.3 kDa seed protein & Ajesh and Sreejith, 2014 \\
\hline & Cryptococcus neoformans & $14.3 \mathrm{kDa}$ seed protein & Ajesh and Sreejith, 2014 \\
\hline & Cladosporium sp. & 14.3 kDa seed protein & Ajesh and Sreejith, 2014 \\
\hline & Cryptococcus albidus & $14.3 \mathrm{kDa}$ seed protein & Ajesh and Sreejith, 2014 \\
\hline & Cryptococcus laurentii & $14.3 \mathrm{kDa}$ seed protein & Ajesh and Sreejith, 2014 \\
\hline & Curvularia sp. & $14.3 \mathrm{kDa}$ seed protein & Ajesh and Sreejith, 2014 \\
\hline & Fusarium oxysporum & $50 \%$ aqueous ethanolic leaf extract & Das and Chatterjee, 2014 \\
\hline & Fusarium solani & Finotin & Kelemu et al., 2004 \\
\hline & Lasiodiplodia theobromae & Finotin & Kelemu et al., 2004 \\
\hline & Pyricularia grisea & Finotin & Kelemu et al., 2004 \\
\hline & Rhizoctonia solani & Finotin & Kelemu et al., 2004 \\
\hline & Rhizopus sp. & $14.3 \mathrm{kDa}$ seed protein & Ajesh and Sreejith, 2014 \\
\hline & Sclerotium sp. & $14.3 \mathrm{kDa}$ seed protein & Ajesh and Sreejith, 2014 \\
\hline
\end{tabular}


Salhan et al., 2011). Using Pheretima posthuma as a test worm, one study showed that the ethanolic $C$. ternatea extract $(50 \mathrm{mg} / \mathrm{mL})$ caused significantly higher mortality rate and incidence of worm paralysis than piperazine citrate, a commonly used drug for controlling parasitic worms (Khadatkar et al., 2008). Similarly, using Eisenia foetida as a test worm, another study showed that the ethanolic and aqueous $C$. ternatea extract induced worm paralysis and mortality at $100 \mathrm{mg} / \mathrm{mL}$ (Salhan et al., 2011). However, compared to the commonly used antiparasitic drug levamisole, the rate of worm paralysis and death was significantly slower in the C. ternatea extracts (Salhan et al., 2011).

\section{Insecticidal Activity}

Proteins and peptides isolated from C. ternatea are reported to exhibit insecticidal properties (Kelemu et al., 2004; Poth et al., 2011a) (Table 5). One study reported 100\% larval mortality when $1 \% \mathrm{w} / \mathrm{w}$ and $5 \% \mathrm{w} / \mathrm{w}$ of the purified C. ternatea protein (20 kDa), finotin, was applied to the bruchids Acanthoscelides obtectus and Zabrotes subfasciatus, respectively (Kelemu et al., 2004). Another study showed that when the C. ternatea cyclotide, Cter M, was incorporated in the diet of the lepidopteran species Helicoverpa armigera, larval growth retardation was observed in a dose dependent manner (Poth et al., 2011a). Larval mortality was observed at $1 \mu \mathrm{mol}$ CterM peptide $\mathrm{g}^{-1}$ diet (Poth et al., 2011a).

Expanding on the initial findings of Poth et al. (2011a), additional studies have reported pesticidal activities of cyclotide extracts from C. ternatea (Gilding et al., 2015; Mensah et al., 2015) (Table 5). Gilding et al. (2015) showed that C. ternatea extracts permeabilized insect-like membrane lipids, with the shoot extracts exhibiting the greatest potency $\left(0.31 \mu \mathrm{g} / \mathrm{mL} \mathrm{LC}_{50}\right)$. Another study reported that application of oil-based C. ternatea mixture $(1-2 \% \mathrm{v} / \mathrm{v})$ to transgenic and conventional cotton crops, resulted in Helicoverpa spp. larval mortality and reduced oviposition and larval feeding (Mensah et al., 2015). Detrimental effects of the extract against beneficial insects were not observed (Mensah et al., 2015), suggesting that C. ternatea extracts could provide the basis for eco-friendly natural insecticides.

\section{Antimicrobial Activity}

The antimicrobial properties of proteins isolated from C. ternatea have previously been described (Kelemu et al., 2004; Ajesh and Sreejith, 2014) (Table 6). The C. ternatea $20 \mathrm{kDa}$ protein finotin demonstrated inhibitory activities over a wide range of plant fungal pathogens (Kelemu et al., 2004). Finotin also exhibited activities against the plant bacterial pathogen Xanthomonas axonopodis (Kelemu et al., 2004). Another study reported isolation of a $14.3 \mathrm{kDa}$ protein from C. ternatea seeds (Ajesh and Sreejith, 2014) that exhibited activities against the human fungal pathogens, Cryptococcus spp. and Candida spp., and against a number of mold fungi (Ajesh and Sreejith, 2014). Studies also reported the antimicrobial properties of $C$. ternatea cyclotides against Gram-negative, but not Gram-positive, bacteria (Nguyen et al., 2011, 2016b).

Ethanol extract of C. ternatea outdoor grown leaves and calli inhibited the growth of the bacterial species Staphylococcus spp., Streptococcus spp., Enterococcus faecalis, and Bacillus spp. (Shahid et al., 2009). On the other hand, the antibacterial activities of the calli aqueous extract were only limited to Bacillus spp. and Streptococcus pyogenes; and activity of the leaf aqueous extract was limited to Bacillus spp. (Shahid et al., 2009). Furthermore, a recent study reported that the ultrasound-assisted aqueous extract of $C$. ternatea leaves and petals inhibited the growth of Staphylococcus aureus (Anthika et al., 2015). C. ternatea petals extracted for 30 min using ultrasound yielded the highest anthocyanin content and also displayed the highest antibacterial activity (Anthika et al., 2015).

The antifungal properties of $C$. ternatea have also been reported (Kamilla et al., 2009; Das and Chatterjee, 2014) (Table 6). Growth of the mold fungus Aspergillus niger was inhibited at a minimum inhibitory concentration of $0.8 \mathrm{mg} / \mathrm{mL}$ of the methanolic C. ternatea leaf extract (Kamilla et al., 2009). Scanning electron microscopy images from the study revealed that addition of the extract lead to conidial and hyphal collapse and distortion which is likely due to cell wall disruption (Kamilla et al., 2009). Another study reported that the 50\% aqueous-ethanolic C. ternatea leaf extract inhibited the growth of Fusarium oxysporum and promoted the activities of amylase, protease and dehydrogenase in $P$. sativum seeds, enzymes that otherwise had low activities during F. oxysporum infestation (Das and Chatterjee, 2014).

\section{PHYTOCHEMICAL COMPOSITION}

\section{Non-proteinaceous Components Flavonols}

As early as 1967, a study reported that C. ternatea seeds contain flavonol glycosides as well as phenolic aglycones, cinnamic acid, and a range of other compounds (Kulshreshtha and Khare, 1967). Nearly two decades later, Saito et al. (1985) reported the isolation of five C. ternatea flavonols, namely kaempferol, kaempferol 3glucoside, kaempferol 3-robinobioside-7-rhamnoside, quercetin, and quercetin 3-glucoside (Saito et al., 1985). Subsequent studies reported the isolation of flavonol glycosides from $C$. ternatea leaves (Morita et al., 1976) and flowers (Kazuma et al., 2003a,b). With some exceptions, the identified flavonol glycosides were found in all C. ternatea lines bearing different floral colors (blue, mauve and white) (Kazuma et al., 2003a). For instance, myricetin 3-(2" -rhamnosyl-6" -malonyl)glucoside, myricetin 3-rutinoside and myricetin 3-glucoside were not detected in the $C$. ternatea line bearing mauve petals (Kazuma et al., 2003a). The flavonols isolated from C. ternatea are summarized in Table 7.

\section{Anthocyanins}

In 1985, six acylated anthocyanins were isolated from blue C. ternatea flowers that were all derivatives of delphinidin $3,3^{\prime}, 5^{\prime}$ triglucoside (Saito et al., 1985). The chemical properties of the acylated C. ternatea delphinidins, which were named ternatins, were further elucidated in subsequent studies (Terahara et al., 1989a, 1990a,b). In 1989, the structure of the largest isolated blue anthocyanin, ternatin A1, was determined (Terahara et al., 1989a). The study also showed that not only was ternatin A1 the largest, it was also one of the most stable in neutral solution 
TABLE 7 | Flavonol and anthocyanin content of Clitoria ternatea.

\begin{tabular}{|c|c|c|c|}
\hline & Compound name & Tissue isolated & References \\
\hline \multirow[t]{11}{*}{ Flavonols } & $\begin{array}{l}\text { Kaempferol; } \\
\text { Kaempferol 3-robinoside-7-rhamnoside }\end{array}$ & Blue flowers & Saito et al., 1985 \\
\hline & Kaempferol 3-glucoside; & $\begin{array}{l}\text { Leaves, blue, mauve, and white } \\
\text { flowers }\end{array}$ & $\begin{array}{l}\text { Morita et al., 1976; Saito et al., 1985; } \\
\text { Kazuma et al., 2003a,b }\end{array}$ \\
\hline & $\begin{array}{l}\text { Kaempferol 3-rutinoside; } \\
\text { Kaempferol 3-neohesperidoside }\end{array}$ & $\begin{array}{l}\text { Leaves, blue, mauve, and white } \\
\text { flowers }\end{array}$ & Morita et al., 1976; Kazuma et al., 2003a,b \\
\hline & $\begin{array}{l}\text { Kaempferol-3-O-rhamnosyl- }(1 \rightarrow 2) \text {-O-[rhamnosyl- } \\
1(1 \rightarrow 6)] \text { glucoside }\end{array}$ & Leaves & Morita et al., 1976 \\
\hline & $\begin{array}{l}\text { Kaempferol } \\
\text { 3-O-(2" }-O-a-\text {-rhamnosyl-6" }{ }^{\prime \prime}-O \text {-malonyl)-b-glucoside; } \\
\text { Kaempferol 3-( }\left(2^{G} \text {-rhamnosylrutinoside }\right)\end{array}$ & Blue, mauve, and white flowers & Kazuma et al., 2003a,b \\
\hline & Quercetin & Blue flowers & Saito et al., 1985 \\
\hline & Quercetin 3-glucoside & & $\begin{array}{l}\text { Saito et al., 1985; Kazuma et al., 2003a,b; } \\
\text { Adhikary et al., } 2017\end{array}$ \\
\hline & $\begin{array}{l}\text { Quercetin } \\
\text { 3-O-(2" -O-a-rhamnosyl-6"'-O-malonyl)-b-glucoside; } \\
\text { Quercetin 3-rutinoside; } \\
\text { Quercetin 3-(2 }{ }^{\mathrm{G}} \text {-rhamnosylrutinoside); } \\
\text { Quercetin 3-neohesperidoside; } \\
\text { Quercetin 3-glucoside; }\end{array}$ & Blue, mauve, and white flowers & Kazuma et al., 2003a,b \\
\hline & Myricetin 3-neohesperidoside; & Blue, mauve, and white flowers & Kazuma et al., 2003a,b \\
\hline & Myricetin 3-(2G-rhamnosylrutinoside) & Blue, mauve, and white flowers & Kazuma et al., 2003a \\
\hline & $\begin{array}{l}\text { Myricetin 3-O- }\left(2^{\prime \prime}, 6^{\prime \prime} \text {-di-O-a-rhamnosyl)- } \beta \text {-glucoside; }\right. \\
\text { Myricetin 3-glucoside; } \\
\text { Myricetin 3-rutinoside }\end{array}$ & Blue and white flowers & Kazuma et al., 2003a,b \\
\hline \multirow[t]{7}{*}{ Anthocyanins } & Ternatin A1, A2, B1, D1 & Blue flowers & $\begin{array}{l}\text { Saito et al., 1985; Terahara et al., 1989a, } \\
\text { 1990a; Kazuma et al., 2003a }\end{array}$ \\
\hline & Ternatin B2, D2 & Blue flowers & $\begin{array}{l}\text { Saito et al., 1985; Terahara et al., 1989a, } \\
\text { 1990a, 1996; Kazuma et al., 2003a }\end{array}$ \\
\hline & Ternatin A3, B3-B4 & Blue flowers & Terahara et al., 1996; Kazuma et al., 2003a \\
\hline & Ternatin C1- C5, D3 & Blue flowers & Terahara et al., 1998; Kazuma et al., 2003a \\
\hline & Preternatin A3 and C4 (demalonylated analogs) & Mostly from young flowers & Terahara et al., 1998 \\
\hline & $\begin{array}{l}\text { Delphinidin } \\
\text { 3-O-(2"'-O-a-rhamnosyl-6"'-O-malonyl)-- } \beta \text {-glucoside; } \\
\text { Delphinidin 3-(6"'-malonyl) glucoside; } \\
\text { Delphinidin 3-neohesperidoside; } \\
\text { Delphinidin 3-glucoside }\end{array}$ & Mauve flowers & Kazuma et al., 2003a \\
\hline & 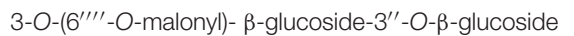 & Blue flowers & Kazuma et al., 2004 \\
\hline
\end{tabular}

(Terahara et al., 1989a). The structure of ternatins A2 (Terahara et al., 1990c), B1 (Kondo et al., 1990), B2 (Terahara et al., 1996), D1 (Terahara et al., 1989b), and D2 (Terahara et al., 1996) were elucidated shortly after.

Subsequent studies isolated and determined the structures of several other novel ternatins isolated from C. ternatea: ternatins A3, B3-B4, C1-C5, D3, and preternatins A3 and C4 (Terahara et al., 1996, 1998) (Table 7). Terahara et al. (1998) observed that lower molecular weight ternatins are more abundant in young flowers while higher molecular weight ternatins are more prevalent in mature flowers. The authors proposed that ternatin $\mathrm{A} 1$ is the final compound, and the other ternatins are intermediate products (Terahara et al., 1998). Starting with ternatin C5, production of ternatin A1 can be achieved via four $p$-coumaric acid acylation steps and four glucosylation steps (Terahara et al., 1998). The biosynthetic pathway of ternatin A1 is summarized in Figure 4 (Terahara et al., 1998). The key enzymatic steps and the biosynthetic pathway to produce ternatin C5 from delphinidin was elucidated in 2004 (Kazuma et al., 2004).

A 2003 study compared the anthocyanin contents of C. ternatea lines bearing different floral colors (Kazuma et al., 2003a). The study showed that white C. ternatea flowers do not produce anthocyanins. Furthermore, unique to the mauve C. ternatea flowers, is the accumulation delphinidins lacking the $3^{\prime}$ and $5^{\prime}$ (polyacelated) glucosyl group substitutions (Kazuma et al., 2003a). The study concluded that glucosylation of delphinidins at these positions are crucial to the production of C. ternatea flowers (Kazuma et al., 2003a).

\section{Other Non-proteinaceous Components}

The pentacyclic triterpenoids, taraxerol and taraxerone, were isolated from C. ternatea roots in the 1960s (Banerjee and Chakravarti, 1963, 1964). Realizing the potential of C. ternatea as a source of taraxerol, in 2008, a method was developed for the routine quantification of the content in $C$. ternatea 


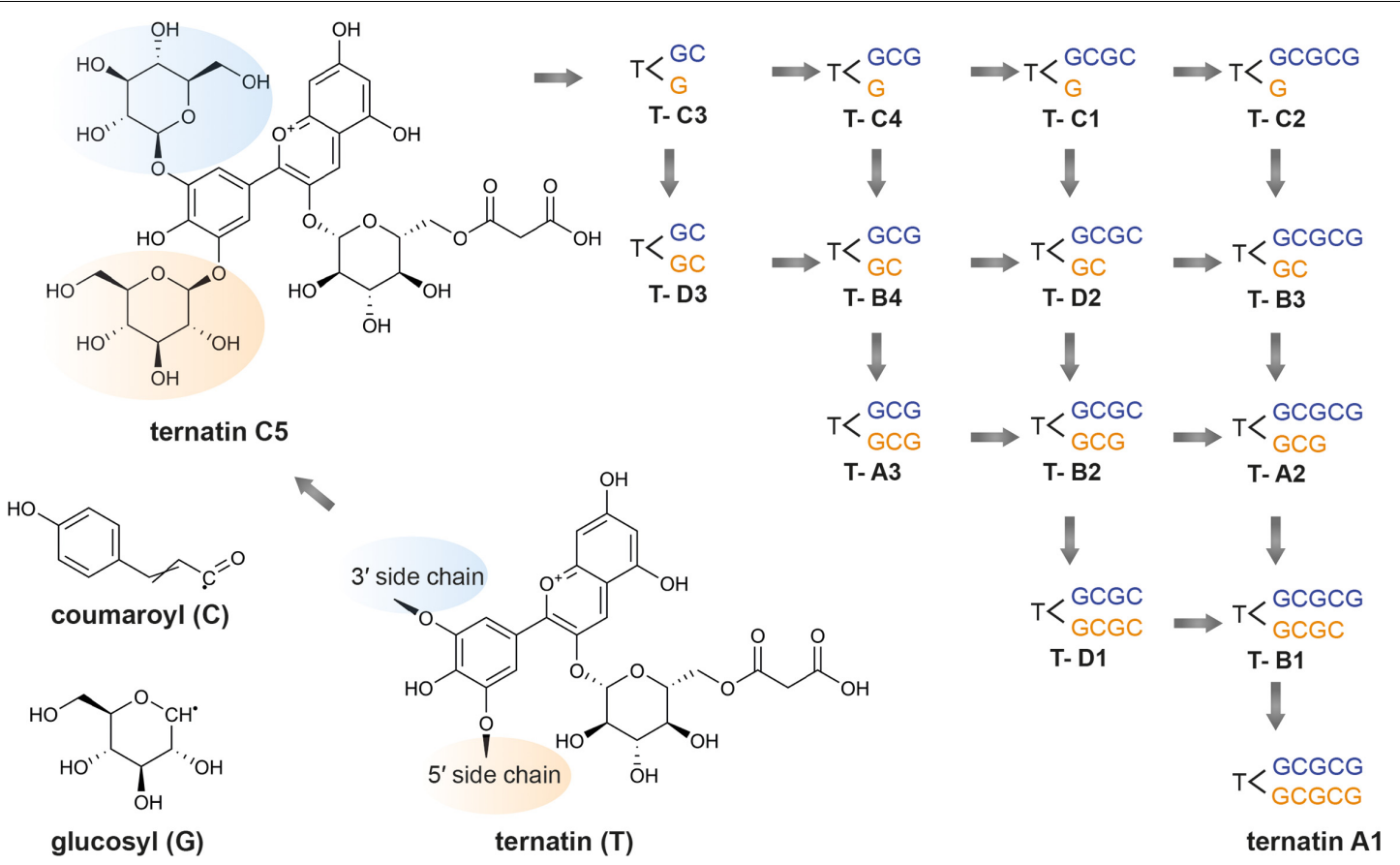

FIGURE 4 | Proposed ternatin biosynthetic pathway. Adapted from Terahara et al. (1998). Beginning with ternatin C5 (PubChem CID 10843319), ternatin A1 (PubChem CID 16173494) can be produced through the addition of four p-coumaroyl (C) and four glucosyl moieties (G) at the $3^{\prime}$ sidechain (in blue) and $5^{\prime}$ sidechain (in orange). The other ternatins are products of the intermediate steps.

extracts of this medicinal compound (Kumar et al., 2008). In 2012, in vitro propagated hairy root cultures were sought as alternative to in vivo grown roots as source of taraxerol (Swain et al., 2012a). In 2016, in addition to taraxerol, novel norneolignans, clitorienolactones A-C, were isolated from C. ternatea roots (Vasisht et al., 2016). C. ternatea floral extracts also contain other types of flavonoids, including rutin (flavone), epicatechin (flavanol) and other polyphenolic acids (gallic acid, protocatechuic acid, and chlorogenic acid) (Siti Azima et al., 2017).

\section{Proteinaceous Components}

In general, there has traditionally been a greater focus in phytochemical studies on the non-protein components of plants and C. ternatea is no exception. However, over the last decade, with advances in nucleic acid sequencing and mass spectroscopic peptide and protein characterization techniques there is now much more focus on proteinaceous components, particularly in the characterization of peptides and proteins implicated in plant defense. Of the known C. ternatea phytochemical components implicated in defense, a class of peptides known as cyclotides is particularly noteworthy (Nguyen et al., 2011; Poth et al., 2011a,b). These peptides mature into cyclic molecules of $\sim 30$ aa from linear precursors through an enzymatic transpeptidation reaction of the peptide backbone. Cyclotides contain three disulfide bonds that form a knot (Figure 5A), similar to configurations seen in linear knottins cataloged across diverse taxa (Gelly et al., 2004). Together, the cyclic and knotted nature of cyclotides makes them highly stable in conditions that would otherwise facilitate peptide degradation (Craik et al., 1999). Unlike linear knottins, which are found across multiple kingdoms of life, cyclotides are restricted to relatively few taxa in Viridiplantae, namely the dicotyledon angiosperms (Gruber et al., 2008). Searching all Viridiplantae sequences for cyclotides using the widely distributed program tblastn, has highlighted the restriction of cyclotides and linear non-cyclotide-like sequences to a handful of plant families discussed below (Altschul et al., 1990).

Despite reports of cyclotide-like sequences in the Poaceae, none of the described sequences have been shown to exist as cyclic molecules in planta, thus failing the definition of the term cyclotide. The taxonomic distribution of cyclotides is often disjointed in a taxonomic group; for instance the taxonomically sparse occurrence of cyclotides observed in the Rubiaceae (Gruber et al., 2008; Koehbach et al., 2013) contrasts with the ubiquitous occurrence of cyclotides in all species tested far-off the Violaceae family (Burman et al., 2015; Göransson et al., 2015). Within the Fabaceae, C. ternatea is the only family member in which cyclotides have been observed despite examination of diverse Fabaceae, including other species of Clitoria (Gilding et al., 2015). Cyclotides are therefore one of the most interesting proteinaceous components of $C$. ternatea. That they are processed from genetically encoded precursor proteins opens opportunities for detecting them either or both as nucleic acid or peptide sequences.

\section{Gene and Transcript Characterization}

RNA-seq experiments to define the transcripts that encode for cyclotides have been performed by several groups. The 

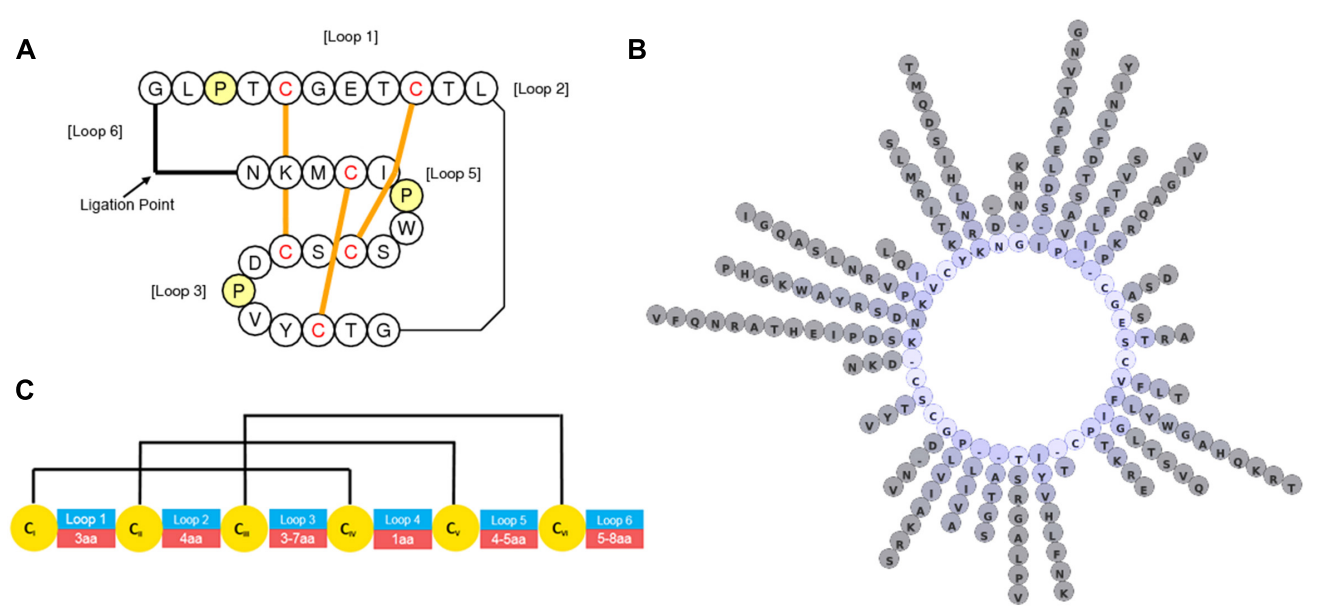

FIGURE 5 | Graphical representations of C. ternatea cyclotide structure and diversity. (A) Topological depiction of Cter M displaying the position and threading of disulfide bonds. (B) Diversity of residues at non-cystine positions of 74 sequence defined $C$. ternatea cyclotides. (C) Loop length diversity and disulfide connectivity map of $C$. ternatea cyclotides.

resulting transcriptomes have allowed the cataloging of at least 74 cyclotide sequences (Table 8) which exhibit high levels of diversity at loops intervening the conserved Cys residues (Figures 5B,C) (Gilding et al., 2015; Nguyen et al., 2016b). All of the precursors observed have singleton cyclotide domains similar to that observed in Petunia x hybrida (Solanaceae), whereas cyclotide precursors from the Cucurbitaceae, Rubiaceae, and Violaceae families possess multiple cyclotide domains (Table 9) (Felizmenio-Quimio et al., 2001; Mylne et al., 2011; Poth et al., 2011a; Koehbach and Gruber, 2015; Park et al., 2017). Unlike precursors from the Cucurbitaceae, Rubiaceae, Solanaceae, and Violaceae, C. ternatea cyclotides are encoded in albumin-1 genes (Poth et al., 2011a).

Pea-like albumin-1 genes are restricted to the tribe Faboideae, as evidenced by the lack of hits when albumin-1 prepropeptide sequences from $P$. sativum are used as queries in a tblastn search on all sequences exclusive of the Faboideae. The canonical albumin-1 gene structure in all taxa examined thus far consists of a signal peptide followed immediately by a b-chain peptide domain with a knottin fold, a short intervening sequence, and a $\sim 54$ aa a-chain domain (Figure 6, Cter M precursor). Typical functions ascribed to the albumin-1 gene family include protein storage and defense through the potentially toxic b-chain. Their function as a toxin is exemplified in the Pisum sativum albumin1 b-chain (Palb), a peptide that effectively kills weevils and select insects through inhibitory activity of insect vacuolar proton pumps (Jouvensal et al., 2003; Chouabe et al., 2011).

Interestingly, the loops between the cystine residues are similar in size and in some cases residue composition between C. ternatea cyclotides and other albumin-1 b-chains (Gilding et al., 2015). This observation implies that the development of cyclotide domains from progenitor albumin-1 b-chains would have involved adaptation of the $\mathrm{b}$-chain into a cyclotide domain structure. A further necessary adaptation to facilitate cyclization is the acquisition of an Asp or Asn residue at the C-terminus of the cyclotide domain. These specific residues are required for cyclization by asparaginyl endopeptideases (AEPs) through a transpeptidation reaction between the C-terminal Asp/Asn residue and the N-terminal residue (Figure 6) (Nguyen et al., 2014; Harris et al., 2015).

In C. ternatea, all transcripts encoding albumin-1 a-chain domains contain a cyclotide domain in place of what would otherwise be the b-chain domain. The complete transition of this region in C. ternatea albumin-1 genes to cyclotide domains implies canonical b-chains were disfavoured in the evolutionary history of C. ternatea (Gilding et al., 2015). The albumin-1 gene family members of $C$. ternatea are $\sim 74$ in number, whereas albumin-1 gene families from the other genome-sequenced Faboideae, Glycine, Medicago, and Phaseolus, are 3, 33, and 17 in number respectively (Goodstein et al., 2012; Gilding et al., 2015; Nguyen et al., 2016b). This observation on albumin-1 gene expansion in C. ternatea further supports the hypothesis that cyclotide domains exhibit qualities and functions that increase fitness.

Transcriptomic expression analysis of various C. ternatea organs illustrates the partitioning of cyclotide expression to certain organs for some precursors, while other precursors are expressed constitutively throughout the examined organs (Gilding et al., 2015). As a class of defense molecules, it is logical that some would be preferentially expressed to target specific threats that different organs may face. Other albumin-1 genes are expressed at a notable level throughout the whole plant. The precursor for Cter $\mathrm{M}$ is an example of a cyclotide that is expressed constitutively, so much so that transcripts encoding Cter M are upward of ninefold higher than the rubisco small subunit in shoots (Gilding et al., 2015). Clearly, the plant is investing large amounts of resources to produce these transcripts and the resulting peptides.

\section{Peptide Characterization}

Clitoria ternatea cyclotides generally have Gly residues at the proto- $\mathrm{N}$-terminus and Asn residues at the proto- $\mathrm{C}$-terminus 
TABLE 8 | Cyclotides in Clitoria ternatea.

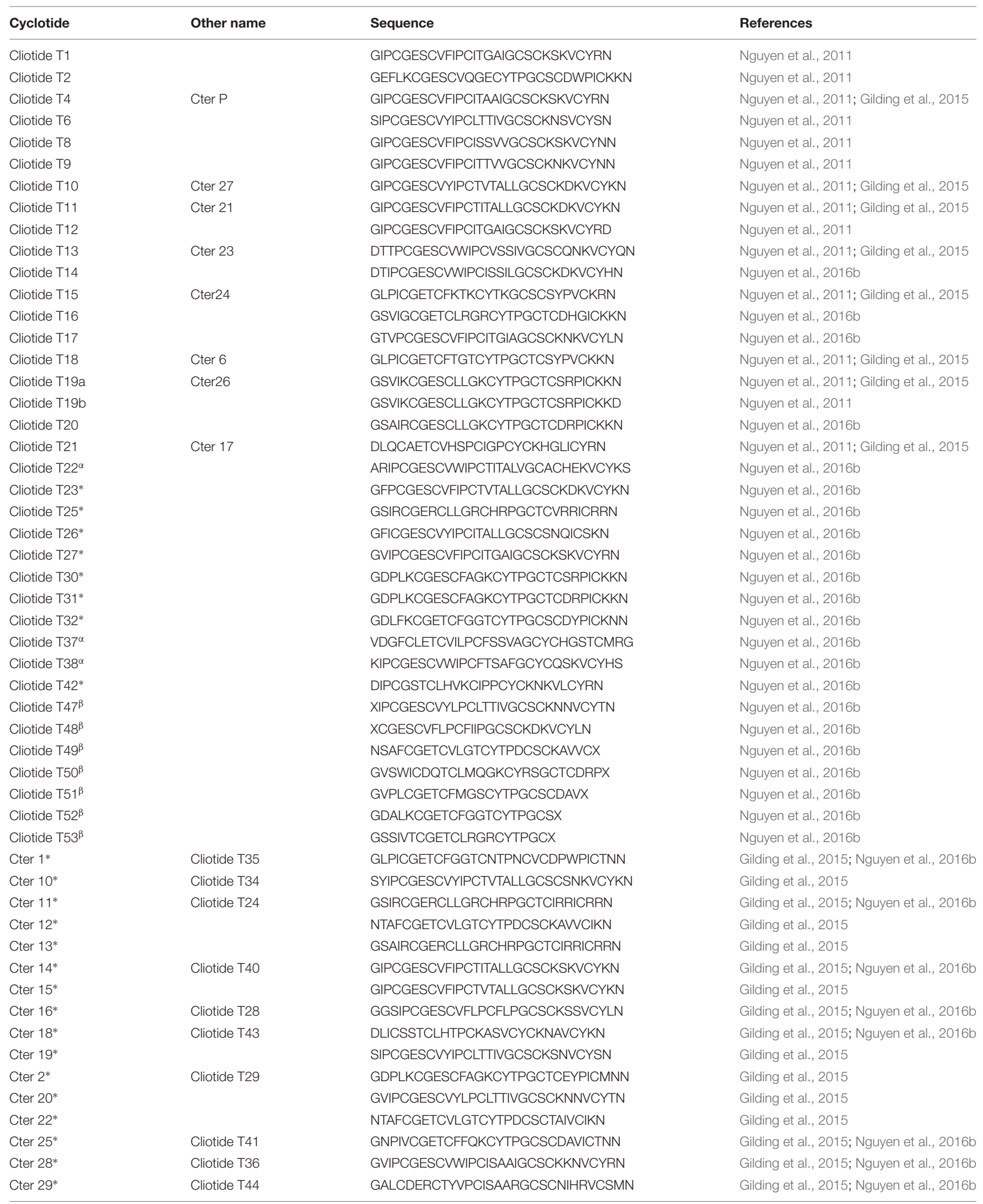


TABLE 8 | Continued

\begin{tabular}{|c|c|c|c|}
\hline Cyclotide & Other name & Sequence & References \\
\hline Cter $3^{*}$ & & GAFCGETCVLGTCYTPDCSCKAWCIKN & Gilding et al., 2015 \\
\hline Cter $30^{*}$ & Cliotide T45 & GFPICGETCFKTKCYTPGCSCSYPVCKKN & Gilding et al., 2015; Nguyen et al., 2016b \\
\hline Cter $31^{*}$ & Cliotide T46 & DLQCAETCVHSPCIGPCYCKHGVICYKN & Gilding et al., 2015; Nguyen et al., 2016b \\
\hline Cter $32^{*}$ & & KIPCGESCVWIPCISSILGCSCKDKVCYHN & Gilding et al., 2015 \\
\hline Cter 33* & & GDLFKCGETCFGGTCYTPGCSCDYPICKKN & Gilding et al., 2015 \\
\hline Cter $34^{*}$ & Cliotide T33 & GFNSCSEACVYLPCFSKGCSCFKRQCYKN & Gilding et al., 2015; Nguyen et al., 2016b \\
\hline Cter $35^{*}$ & & GAFCGETCVLGTCYTPGCSCAPVICLNN & Gilding et al., 2015 \\
\hline Cter 36* & & GSPTCGETCFGGTCYTPNCVCDPWPICTKN & Gilding et al., 2015 \\
\hline Cter $37^{*}$ & & GSPTCGETCFGGTCYTPGCVCDPWPICTKN & Gilding et al., 2015 \\
\hline Cter $4^{*}$ & Cliotide T39 & GDPLACGETCFGGTCYTPGCVCDPWPICTKN & Gilding et al., 2015; Nguyen et al., 2016b \\
\hline Cter $5^{*}$ & & GEFLKCGESCVQGECYTPGCSCDYPICKNN & Gilding et al., 2015 \\
\hline Cter $7^{*}$ & & GDPFKCGESCFAGKCYTPGCTCEYPICMNN & Gilding et al., 2015 \\
\hline Cter $8^{*}$ & & GSAFCGETCVLGTCYTPDCSCKAWCIKN & Gilding et al., 2015 \\
\hline Cter 9* & & GIPCGESCVYIPCTVTALLGCSCRDKVCYKN & Gilding et al., 2015 \\
\hline Cter A & & GVIPCGESCVFIPCISTVIGCSCKNKVCYRN & Poth et al., 2011a,b \\
\hline Cter B & & GVPCAESCVWIPCTVTALLGCSCKDKVCYLN & Poth et al., 2011b \\
\hline Cter C & & GVPCAESCVWIPCTVTALLGCSCKDKVCYLD & Poth et al., 2011b \\
\hline Cter D & & GIPCAESCWWIPCTVTALLGCSCKDKVCYLN & Poth et al., 2011b \\
\hline Cter E & & GIPCAESCWWIPCTVTALLGCSCKDKVCYLD & Poth et al., 2011b \\
\hline Cter F & & GIPCGESCVFIPCISSWGCSCKSKVCYLD & Poth et al., 2011b \\
\hline Cter $\mathrm{G}$ & & GLPCGESCVFIPCITTWGCSCKNKVCYNN & Poth et al., 2011b \\
\hline Cter $\mathrm{H}$ & & GLPCGESCVFIPCITTWGCSCKNKVCYND & Poth et al., 2011b \\
\hline Cter I & & GTVPCGESCVFIPCITGIAGCSCKNKVCYIN & Poth et al., 2011b \\
\hline Cter J & & GTVPCGESCVFIPCITGIAGCSCKNKVCYID & Poth et al., 2011b \\
\hline Cter K & & HEPCGESCVFIPCITTVVGCSCKNKVCYN & Poth et al., 2011b \\
\hline Cter L & & HEPCGESCVFIPCITTWVGCSCKNKVCYD & Poth et al., 2011b \\
\hline Cter M & Cliotide T3 & GLPTCGETCTLGTCYVPCSCSWPICMKN & Nguyen et al., 2011; Poth et al., 2011a \\
\hline Cter N & & GSAFCGETCVLGTCYTPDCSCTALVCLKN & Poth et al., 2011b \\
\hline Cter $\mathrm{O}$ & & GIPCGESCVFIPCITGIAGCSCKSKVCYRN & Poth et al., 2011a \\
\hline Cter Q & Cliotide T5 & GIPCGESCVFIPCISTVIGCSCKNKVCYRN & Nguyen et al., 2011; Poth et al., 2011a \\
\hline Cter R & Cliotide T7 & GIPCGESCVFIPCTVTALLGCSCKDKVCYKN & Nguyen et al., 2011; Poth et al., 2011a \\
\hline Cterneg_C1 $1^{\alpha}$ & & GSPLLRGETCVLQTCYTPGCSCTIAICLNN & Gilding et al., 2015 \\
\hline
\end{tabular}

*No mass spec data available; ${ }^{\alpha}$ predicted to be non-cyclic; ${ }^{\beta}$ low confidence sequences.

TABLE 9 | Characteristics of cyclotide gene precursors.

\begin{tabular}{|c|c|c|c|c|c|}
\hline \multicolumn{2}{|l|}{ Taxonomy } & \multicolumn{4}{|c|}{ Precursor characters } \\
\hline Family & Exemplary species & $\begin{array}{l}\text { Signal peptide to cyclotide } \\
\mathrm{N} \text {-terminal junction present }\end{array}$ & $\begin{array}{l}\mathrm{N} \text {-terminal pre- } \\
\text { sequence present }\end{array}$ & $\begin{array}{l}\text { Multimeric or singleton } \\
\text { cyclotide domains present }\end{array}$ & $\begin{array}{c}\text { C-terminal sequence } \\
\text { type }\end{array}$ \\
\hline Cucurbitaceae & $\begin{array}{c}\text { Momordica } \\
\text { cochinchinensis }\end{array}$ & $\mathrm{N}$ & Y & Multimeric & $\begin{array}{l}\text { None, except final } \\
\text { repeat is acyclic }\end{array}$ \\
\hline Fabaceae & Clitoria ternatea & $Y$ & $\mathrm{~N}$ & Singleton & $\begin{array}{l}\text { Linker and albumin-1 } \\
\text { a-chain domain }\end{array}$ \\
\hline Rubiaceae & Oldenlandia affinis & $\mathrm{N}$ & Y & Both & Short, $\sim 5$ aa \\
\hline Solanaceae & Petunia x hybrida & $\mathrm{N}$ & Y & Singleton & Short, $\sim 5$ aa \\
\hline Violaceae & Viola tricolor & $N$ & Y & Both & Short, $\sim 5$ aa \\
\hline
\end{tabular}

of the cyclotide domain within the precursor proteins, similar to the case from other plant families. By contrast with the conserved terminal residues, the intervening backbone loops between the conserved Cys residues tend to be variable in size and sequence. Some of the biophysical properties of $C$. ternatea cyclotides deviate notably from peptides of other cyclotideproducing plant families. For example, Cter 13 contains eight Arg residues that confer a predicted charge of +7 and $\mathrm{pI}$ of 10, well above that predicted for MCoTI-I, which contains four Arg residues, from the Cucurbit Momordica cochinchinensis 


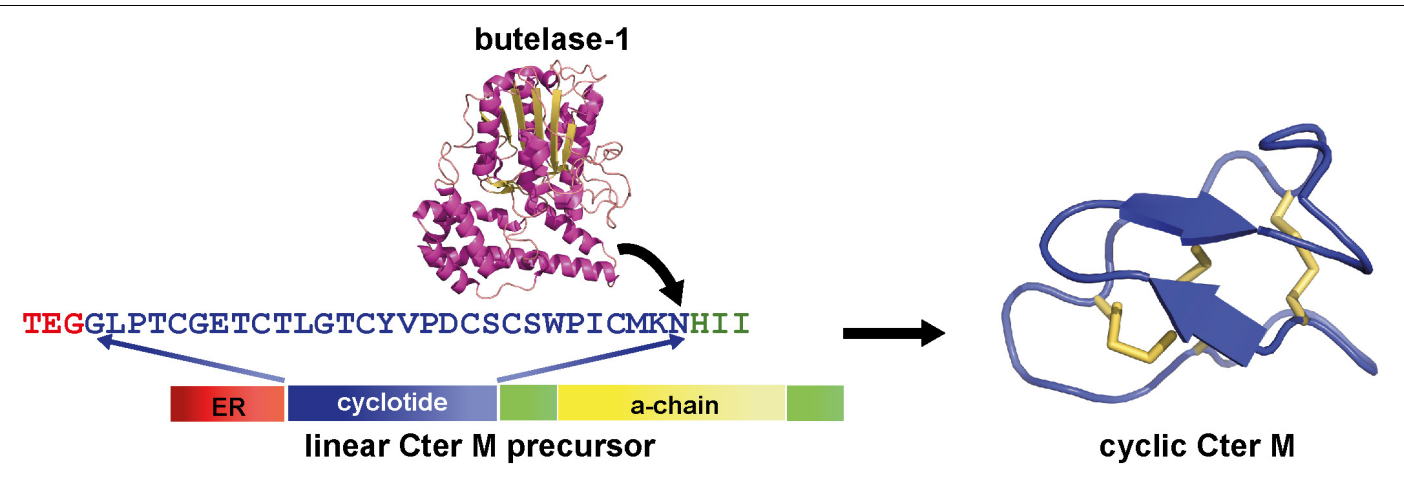

FIGURE 6 | Structure of a Fabaceae albumin-1 cyclotide prepropeptide exemplified by Cter M. The linear Cter M precursor consists of the endoplasmic reticulum (ER) signal (red), the cyclotide domain (blue) which replaces the typical Fabaceae albumin-1 b-chain, the a-chain (yellow) and the C-terminal interlinker region (green). A specialized asparaginyl endopeptidease (AEP, butelase-1 (PDB code: 6DHI) effects head-to-tail cyclization of the Cter M domain of the precursor in planta and results in a mature CterM cyclotide (PDB code: 2LAM).

(Felizmenio-Quimio et al., 2001; Mylne et al., 2012). The more highly charged and high-pI cyclotides of $C$. ternatea are preferentially expressed in organs that encounter challenges from the soil, namely the roots and seeds of the plant. Cyclotide extracts from roots, compared to leaves, exhibit increased toxicity against the juvenile L1 stage of the model nematode C. elegans, whereas adults and late stage juveniles were not affected (Gilding et al., 2015). The high charge of these potentially nematicidal peptides in on trend with other described nematicidal peptides (Liu et al., 2011). Further study is required to test for specific activity of organ-specific cyclotides against organisms.

Cyclotide sequences observed in aerial tissue typically have lower predicted charges and pI values than cyclotides in soilcontacting tissues. Cyclotide extracts of these aerial tissues exhibit a different MALDI-MS profile compared to other plant parts and greater propensity to bind to insect-mimetic plasma membranes. This implies that the aerially-expressed cyclotides are targeting insects (Gilding et al., 2015).

The cyclotide diversity of C. ternatea is further increased by post-translational modifications (PTM). Serra et al. (2016) described the first observations of hexosylation and methylation of cyclotides through enzymatic digests and MS techniques, with the estimated cyclotide diversity conferred by primary sequence and PTM diversity numbering in the hundreds. What the function of these post-translational modifications may be remains to be defined. Modifications of amino acid side chains reported in cyclotides include oxidation (Met and Trp), methylation, deamination (common at C-terminal Asn to Asp), hexosylation, dehydration, and hydroxylation (select Pro residues) (Plan et al., 2007; Serra et al., 2016).

\section{Biosynthetic Auxiliary Enzymes}

Cyclotide transcripts of $C$. ternatea encode for a signal peptide that immediately precedes the $\mathrm{N}$-terminal residue of the cyclotide domain (Poth et al., 2011a; Gilding et al., 2015; Nguyen et al., 2016b). The current model for C. ternatea cyclotide biosynthesis mimics that of other cyclotide producing species and begins with the signal peptide inducing the docking of the ribosome-transcript complex with the rough endoplasmic reticulum (ER) (Conlan and Anderson, 2011; Göransson et al., 2015). Unique to $C$. ternatea cyclotide precursors is that the signal peptide cleavage alone releases the $\mathrm{N}$-terminus of the cyclotide domain, thus no other N-terminal processing proteases are required. Following this, it is postulated that folding of the cyclotide domain begins, presumably aided by protein disulfide isomerases (PDIs), as the propeptide is held within the ER. From there the folded propeptide is transported via vesicles to the Golgi, and later to prevacuolar or vacuolar compartments. Somewhere during this transport pathway the propeptide encounters a specific type of AEP that catalyzes the simultaneous cyclization and cleavage of the cyclotide domain from the precursor (Göransson et al., 2015; Jackson et al., 2018). Post-translational modifications are possibly acquired along the maturation pathway but are poorly defined and thus need further investigation (Serra et al., 2016).

\section{Protein disulfide isomerases}

The disulfide knot of cyclotides must be formed from the oxidation of the six cysteine residues in a specific order. Incorrect connectivity may result in the precursor not being able to be cyclized and flagged as a faulty molecule needing destruction. In all cyclotide producing taxa, the specific in vivo physical of genetic interactions of PDI family members and cyclotide precursors is not known. In vitro evidence for PDI involvement is known from a PDI cloned in the Rubiaceae plant, Oldenlandia affinis, however, under the conditions tested the isolated PDI was not as efficient as using an isopropanol buffer to effect proper disulfide bond formation (Gruber et al., 2007). A systematic in vivo examination of $C$. ternatea PDIs discovered in the transcriptome is hindered by the lack of reverse genetic resources in C. ternatea.

\section{Asparaginyl endopeptidases}

Asparaginyl endopeptidases (AEPs), like most proteases, are known primarily for their function in peptide bond hydrolysis (Yamada et al., 2005), thus a proposed role for peptide bond creation for a selection of AEPs is particularly intriguing. The first direct evidence for this came about through work by the Tam group (Nguyen et al., 2014), who set out to identify 
the peptide ligase responsible for the maturation of cyclotides in C. ternatea. Through activity-guided protein-fractionation studies, the researchers identified a single $C$. ternatea AEP isoform (termed butelase-1) that was highly efficient in intermolecular peptide cyclization. Since the discovery of butelase-1 in 2014, several other AEP peptide ligases have been identified from cyclotide producing plant species, including OaAEP1 $1_{b}$ from O. affinis (Harris et al., 2015), PxAEP3b (Petunia $\mathrm{x}$ hybrida) (Jackson et al., 2018), and HeAEP3 (Hybanthus enneaspermus) (Jackson et al., 2018). Through bioinformatic and functional testing the structural features that differentiate AEP ligases from proteases are beginning to emerge. Specifically, plant AEPs that function as transpeptidase-preferring enzymes in vivo have been shown to possess specific markers in their protein sequence, most notably one termed the Marker for Ligase Activity (MLA) (Jackson et al., 2018).

Subsequent work by Gilding et al. defined the expression levels of butelase-1 (referred to as CtAEP1) and the full length sequence of butelase-2/CtAEP2, CtAEP3, and CtAEP5 via RNAseq (Gilding et al., 2015). In contrast, a total of six butelases were described by Nguyen et al. (2014), with assembled sequences for butelase-4 and -6 not showing any homology to any of the CtAEPs described by Gilding et al. (2015). It might be the case that there is natural AEP isoform variation amongst C. ternatea accessions, or that differences in data assembly conditions, or choice of tissue RNA sampled between the studies of Nguyen et al. (2014) and Gilding et al. (2015) are responsible for this apparent discrepancy. Importantly, of all six AEPs, only butelase-1 has been shown to prefer transpeptidation over proteolysis.

\section{NEXT GENERATION APPLICATIONS}

In this section we describe recent applications of C. ternatea components in biotechnological, agricultural and pharmaceutical industries.

\section{Butelase}

Butelase-1 has proven to be a very versatile molecular tool for a range of in vitro peptide engineering applications (Nguyen et al., 2016a,c; Bi et al., 2017). When compared to other characterized AEP ligases, butelase-1 displays superior reaction kinetics. Despite this, one obvious limitation for end-user uptake is that a recombinant production system is yet to be established (Nguyen et al., 2014). In lieu of this, a detailed protocol for the purification of butelase- 1 from $C$. ternatea seed pods is available (Nguyen et al., 2016c), but is restricted to those with access to the source material and protein purification expertise. It remains unclear if butelase-1 has evolved superior structural features over other AEP ligases or that its greater catalytic efficiency is a by-product of purifying source activated enzyme.

\section{Butelase-1 Mediated Intramolecular Peptide/Protein Cyclization}

Tools to enable backbone cyclization of peptides have garnered considerable interest from the pharmaceutical industry as a means to provide proteolytically stable peptide therapeutics (Craik et al., 2012). In this regard, butelase-1 has been demonstrated as a highly versatile enzyme, cyclizing a range of diverse peptides, including cysteine rich cyclotides, conotoxins (e.g., MrIA) and sunflower trypsin inhibitors (SFTI-1) (Nguyen et al., 2014). Additionally a wide range of non-cysteine containing peptides have been cyclized, including human apelin, galanin, neuromedin U and salusin (Nguyen et al., 2015). In all cases, the substrate requirements for cyclization include the introduction of, if not already present, an Asn residue at the peptide ligation point, which must be linked to the $\mathrm{C}$-terminal tailing residues of His-Val. These tailing residues, which are subsequently cleaved off and are not incorporated into the final cyclized product have been shown to be essential for butelase-1 cyclization efficiency (Nguyen et al., 2014). At the substrates N-terminus, requirements are flexible at the $\mathrm{P} 1$ ' position, with all residues accepted apart from Pro. However, at the P2' position more stringent requirements exist, with Cys, Ile, Leu, and Val all preferred (Nguyen et al., 2014). Together these requirements mean that most peptides, require at least some modifications of the termini residues to allow butelase-1 mediated cyclization. When these substrate requirements are met, butelase- 1 has remarkably catalytic efficiency, with substrate to enzyme ratios of $100 \sim$ 1000:1 commonly used, with typical cyclization reactions completed within $5 \sim 30$ min (Nguyen et al., 2015).

The benefits of backbone cyclization are not limited to small peptides, with the thermal and proteolytic stability of a number of larger proteins also improved by backbone cyclization. Like smaller peptides, these proteins must first be engineered to include optimal flanking residues for butelase1 activity, with specific consideration given to the proximity of $\mathrm{N}$ and $\mathrm{C}$ residues. Where termini are not held close enough together, considerations should be given to include appropriate sized linker sequences. Using butelase-1, three different recombinantly produced proteins have been successfully cyclized, including green fluorescent protein (GFP), interleukin1 receptor antagonist (IL-1Ra) and human growth hormone (somatropin) (Nguyen et al., 2015). In all cases butelase-1 $(0.1 \mathrm{uM})$ and target protein $(25 \mu \mathrm{M})$ were incubated together with cyclization essentially complete within $15 \mathrm{~min}$. In the case of IL-1Ra, backbone cyclization was shown to increase the thermostability of the protein, without affecting biological activity (Nguyen et al., 2015).

\section{Butelase-1 Mediated Intermolecular Peptide Bond Formation}

Butelase-1 has additionally shown great potential for the selective labeling of proteins by intermolecular peptide bond formation. Here, butelase-1 recognizes the required NHV motif engineered into a protein of interest and initiates ligation of incoming intermolecular nucleophiles, provided that substrate requirements are met. In this way a protein of interest can be labeled with any number of functional cargoes. Site specific labeling of proteins has applications for elucidating cellular pathways, defining protein-protein interactions and for the development of innovative medical imaging approaches and therapeutics (Falck and Müller, 2018; Harmand et al., 2018). One 
additional promising application is the site specific labeling of surface proteins of live bacteria (Bi et al., 2017). To accomplish this, the authors engineered an NHV motif to the C-terminus of the anchoring protein OmpA of Escherichia coli. Upon incubation of live cells with butelase-1, a range of cargo molecules were able to be successfully linked to the engineered bacterial surface protein OmpA. These included a fluorescein probe, useful for cellular tracking of pathogen response, and a tumor associated monoglycosylated peptide, which provided a proof of concept for delivering post translationally modified antigens as live bacteria vaccines.

\section{Insecticidal Applications of C. ternatea Peptide Extracts}

Conventional pesticides have for decades been of paramount importance in sustaining agricultural productivity under an ever-increasing population burden. However, many traditional pesticides are increasingly becoming disfavored due to off-target toxicities and human health concerns. These concerns, together with increasing incidences of insects developing resistance mechanisms necessitates the discovery or engineering of novel pesticides with new modes of action (Perry et al., 2011). Recently an organic ethanolic extract prepared from C. ternatea vegetative tissue has shown promising insecticidal activity against a wide range of crop pests ${ }^{3}$. The extract, termed Sero$\mathrm{X}^{\circledR}$ has thus far been registered in Australia for applications in cotton and macadamia, with further applications pending both in Australia and overseas. Although the exact mode of action of this ethanolic extract remains to be determined, it is likely in part to be due to the high concentrations of C. ternatea cyclotides present (Poth et al., 2011a,b; Gilding et al., 2015). The prototypic C. ternatea cyclotide Cter $M$ is indeed enriched in the Sero- $\mathrm{X}^{\circledR}$ extract and when tested in isolation, displays lethality against cotton budworm (H. armigera) (Poth et al., 2011a). Like other cyclotides, such as kalata B1 from O. affinis, the predicted mode of action is through insect cell membrane disruption (Poth et al., 2011a; Craik, 2012), but it remains unclear if other non-proteinaceous components present in the Sero- $\mathrm{X}^{\circledR}$ extract play a synergistic role. Importantly, Sero- $\mathrm{X}^{\circledR}$ displays no toxicity to tested rodents or bee pollinators, and is considered non-hazardous according to the Globally Harmonized System of Classification and labeling of Chemicals.

\section{Food Colorants/Consumer Products}

Butterfly pea flowers can range from white to intense blue to shades in between. This coloring largely stems from the anthocyanin content and degree of aromatic acylation (Kazuma et al., 2003a). The deep blue pigment of C. ternatea has been particularly popular in Asia, where flower petals are used to color teas, deserts and clothes. More recently, C. ternatea flower extracts have been used to create vibrant blue alcoholic gins ${ }^{4}$, which change color depending on the $\mathrm{pH}$, such as occurs on mixing with tonic water or lime. Specifically, the

${ }^{3}$ https://innovate-ag.com.au/

${ }^{4} \mathrm{https} / / /$ www.inkgin.com/ deep blue color of $C$. ternatea flowers is a particularly sought after alternative to synthetic blue food colorants which have become increasingly disfavored due to health concerns (Nigg et al., 2011). Studies reported that addition of C. ternatea extracts increased the polyphenolic and antioxidant contents of sponge cakes (Pasukamonset et al., 2018), enhanced the oxidative stability of cooked pork patties (Pasukamonset et al., 2017) and reduced the predicted glycemic index of flour (Chusak et al., 2018a). Microencapsulation using alginate prevented the degradation and enhanced the retainment of the antioxidant activities of $C$. ternatea polyphenolic extracts post gastrointestinal digestion (Pasukamonset et al., 2016). Currently there exists no commercial scale production of $C$. ternatea for anthocyanins, with harvesting of plant material at largescale not likely to be economically feasible. However, recent advances in engineering plant cell suspension cultures with anthocyanin regulatory pathway genes offers an alternative approach (Appelhagen et al., 2018).

\section{CONCLUSION AND FUTURE OUTLOOK}

Here we have attempted to provide a comprehensive and multidisciplinary account of the diverse properties and applications of $C$. ternatea and its constituent molecules. The plant is readily grown in a range of habitats and there is wide opportunity for it to be used for rotational cropping to aid in soil nitrogen regeneration, as a fodder crop for cattle, or as source of novel phytochemicals. There are already a host of cosmetic and food colorants on the market and the first $C$. ternatea based insecticide $\left(\right.$ Sero- $\left.\mathrm{X}^{\circledR}\right)$ is also approved and being used for insect control on cotton and macadamia nut crops. The butelase-1 enzyme derived from $C$. ternatea pods is also creating a lot of interest as a biotechnological tool for peptide ligation and cyclization.

We anticipate that the success of products (including enzymes, extracts, and purified phytochemicals) deriving from C. ternatea will encourage more research on this plant and stimulate further discoveries that might lead to second and third generation products. For example, so far only a small fraction of the more than 70 cyclotides in this plant have been tested for pesticidal activity and there may be components in this cocktail of cyclotides that are significantly more potent as pesticides than what is currently known. Further work is needed to understand the biotic and abiotic factors that modulate the production of individual cyclotides in this plant and to understand possible synergies between different cyclotides and between cyclotides and non-cyclotide components.

We also anticipate that there will be more studies in the future on pharmaceutical applications of $C$. ternatea components. The ability to harvest large amounts of plant material means that one of the limitations encountered in many natural product research and commercialization (i.e., lack of source material) is not a factor for C. ternatea. While the multitude of medicinal applications reported so far from various $C$. ternatea preparations are impressive, we caution that many of these are one-off studies that have yet to be independently validated by groups other 
than the original reporting group. It is to be expected that the claims for the various bioactivities of plant extracts need to be tested with rigorous controls to establish the efficacy of the plant components. Furthermore, very few of the cyclotides in C. ternatea have been screened for medicinal applications and we feel this would be a useful exercise for future studies. Likewise, none of the C. ternatea cyclotides have yet been used as molecular grafting frameworks to introduce new desired pharmaceutical activities as has been done for cyclotides from other plants such as kalata B1 or MCoTI-II. With these suggestions for future work on this fascinating plant we feel that many more exciting discoveries are on the horizon.

\section{REFERENCES}

Abdelhamid, A. M., and Gabr, A. A. (1993). The evaluation of new sources of fodder (Clitoria and Phillipesara) under Egyptian conditions. Arch. Anim. Nutr. 44, 85-93. doi: 10.1080/17450399309386060

Adhikary, R., Sultana, S., and Bishayi, B. (2017). Clitoria ternatea flower petals: effect on TNFR1 neutralization via downregulation of synovial matrix metalloproteases. J. Ethnopharmacol. 210, 209-222. doi: 10.1016/j.jep.2017. 08.017

Ajesh, K., and Sreejith, K. (2014). A novel antifungal protein with lysozyme-like activity from seeds of Clitoria ternatea. Appl. Biochem. Biotechnol. 173, 682-693. doi: 10.1007/s12010-014-0880-8

Alderete-Chavez, A., Guerra-Santos, J. J., Cruz-Landero De la, N., Brito, R., Gelabert, R., Endanu, E., et al. (2011). Evaluation of Clitoria ternatea L. in relation with fertility in tropical soils. J. Appl. Sci. 11, 1044-1048. doi: 10.3923/ jas.2011.1044.1048

Altschul, S. F., Gish, W., Miller, W., Myers, E. W., and Lipman, D. J. (1990). Basic local alignment search tool. J. Mol. Biol. 215, 403-410. doi: 10.1016/S00222836(05)80360-2

Anthika, B., Kusumocahyo, S. P., and Sutanto, H. (2015). Ultrasonic approach in Clitoria ternatea (butterfly pea) extraction in water and extract sterilization by ultrafiltration for eye drop active ingredient. Procedia Chem. 16, 237-244. doi: $10.1016 /$ j.proche.2015.12.046

Appelhagen, I., Wulff-Vester, A. K., Wendell, M., Hvoslef-Eide, A.-K., Russell, J., Oertel, A., et al. (2018). Colour bio-factories: towards scale-up production of anthocyanins in plant cell cultures. Metab. Eng. 48, 218-232. doi: 10.1016/j. ymben.2018.06.004

Banerjee, S. K., and Chakravarti, R. N. (1963). Taraxerol from Clitoria ternatea Linn. Bull. Calcutta Sch. Trop. Med. 11, 106-107.

Banerjee, S. K., and Chakravarti, R. N. (1964). Taraxerone from Clitoria ternatea Linn. Bull. Calcutta Sch. Trop. Med. 12:23.

Barro, C., and Ribeiro, A. (1983). The study of Clitoria ternatea L. hay as a forage alternative in tropical countries. Evolution of the chemical composition at four different growth stages. J. Sci. Food Agric. 34, 780-782. doi: 10.1002/jsfa. 2740340803

Bhatia, M., Chahal, J., and Gupta, S. (2014). Analgesic and anti-inflammatory activities of Clitoria ternatea Linn. leaves extract on rat model. Int. J. Pharm. Sci. Res. 5, 600-606. doi: 10.13040/IJPSR.0975-8232.5(2).600-06

Bi, X., Yin, J., Nguyen, G. K. T., Rao, C., Halim, N. B. A., Hemu, X., et al. (2017). Enzymatic engineering of live bacterial cell surfaces using butelase 1. Angew. Chem. 56, 7822-7825. doi: 10.1002/anie.201703317

Biyoshi, A. K., and Geetha, K. A. (2012). Polymorphism in flower colour and petal type in Aparajita (Clitoria ternatea). Open Access J. Med. Aromat. Plants 3, $12-14$.

Burman, R., Yeshak, M. Y., Larsson, S., Craik, D. J., Rosengren, K. J., and Göransson, U. (2015). Distribution of circular proteins in plants: large-scale mapping of cyclotides in the Violaceae. Front. Plant Sci. 6:855. doi: 10.3389/ fpls.2015.00855

Chouabe, C., Eyraud, V., Da Silva, P., Rahioui, I., Royer, C., Soulage, C., et al. (2011). New mode of action for a knottin protein bioinsecticide: pea albumin 1 subunit b (PA1b) is the first peptidic inhibitor of V-ATPase. J. Biol. Chem. 286, 36291-36296. doi: 10.1074/jbc.M111.281055

\section{AUTHOR CONTRIBUTIONS}

DC and GO conceived and planned the framework for this article. All authors contributed to the writing and editing.

\section{ACKNOWLEDGMENTS}

We thank Innovate Ag Pty. Ltd for the financial support through an Australian Research Council (ARC) Linkage grant (LP130100550). DC is an Australian Research Council Australian Laureate Fellow (FL150100146).

Chusak, C., Henry, C., Chantarasinlapin, P., Techasukthavorn, V., and Adisakwattana, S. (2018a). Influence of Clitoria ternatea flower extract on the in vitro enzymatic digestibility of starch and its application in bread. Foods 7:102. doi: 10.3390/foods7070102

Chusak, C., Thilavech, T., Henry, C. J., and Adisakwattana, S. (2018b). Acute effect of Clitoria ternatea flower beverage on glycemic response and antioxidant capacity in healthy subjects: a randomized crossover trial. BMC Complement. Altern. Med. 18:6. doi: 10.1186/s12906-017-2075-7

Cobley, L. S. (1956). An Introduction to the Botany of Tropical Crops. Bristol: Western Printing Services LTD.

Colina, V., Clavero, T., Razz, R., and Castro, C. (1997). Effect of defoliation on biomass production of Clitoria ternatea L. Cuban J. Agric. Sci. 31, 113-117.

Conlan, B. F., and Anderson, M. A. (2011). Circular micro-proteins and mechanisms of cyclization. Curr. Pharm. Des. 17, 4318-4328. doi: 10.2174/ 138161211798999410

Conway, M. (2005). "Planting and establishment," in The Butterfly Pea Book: a Guide to Establishing and Managing Butterfly Pea Pastures in Central Queensland, eds R. Collins and T. Grundy (Brisbane: Department of Primary Industries and Fisheries), 19-27.

Conway, M., and Collins, R. (2005). "Climate and soils," in The Butterfly Pea Book: a Guide to Establishing and Managing Butterfly Pea Pastures in Central Queensland, eds R. Collins and T. Grundy (Brisbane: Department of Primary Industries and Fisheries), 16-18.

Conway, M., and Doughton, J. (2005). "Introduction," in The Butterfly Pea Book: a Guide to Establishing and Managing Butterfly Pea Pastures in Central Queensland, eds R. Collins and T. Grundy (Brisbane: Department of Primary Industries and Fisheries), 6-9.

Conway, M. J., McCosker, K., Osten, V., Coaker, S., and Pengelly, B. C. (2001). "Butterfly pea - A legume success story in cropping lands of Central Queensland," in Proceedings of the 10th Australian Agronomy Conference, eds B. Rowe, N. Mendham, and D. Donaghy (Hobart: The Regional Institute).

Craik, D. J. (2012). Host-defense activities of cyclotides. Toxins 4, 139-156. doi: $10.3390 /$ toxins4020139

Craik, D. J., Daly, N. L., Bond, T., and Waine, C. (1999). Plant cyclotides: a unique family of cyclic and knotted proteins that defines the cyclic cystine knot structural motif. J. Mol. Biol. 294, 1327-1336. doi: 10.1006/jmbi.1999. 3383

Craik, D. J., Swedberg, J. E., Mylne, J. S., and Cemazar, M. (2012). Cyclotides as a basis for drug design. Expert Opin. Drug Discov. 7, 179-194. doi: 10.1517/ 17460441.2012.661554

Cruz, M. S. D., Perez-Urria, E., Martin, L., Avalos, A., and Vicente, C. (1995). Factors affecting germination of Canavalia brasiliensis, Leucaena leucocephala, Clitoria ternatea and Calopogonium mucunoides seeds. Seed Sci. Technol. 23, $447-454$.

Das, N., and Chatterjee, P. (2014). Antifungal effect of Clitoria ternatea leaf extract on seeds of Pisum sativum in relation to the activities of some enzymes. Int. J. Res. Ayurveda Pharm. 5, 99-101. doi: 10.7897/2277-4343.05120

De Souza, E. S., Burity, H. A., Oliveira, J. D., Figueiredo, M. D. B., and DeLyra, M. D. C. P. (1996). N2-fixation and growth of the calopogonium (Calopogonium mucunoides Desv.) and of the Clitoria (Clitoria ternatea L.) after sucessive cuts R. Soc. Bras. Zootec. 25, 1036-1048. 
Devi, B. P., Boominathan, R., and Mandal, S. C. (2003). Anti-inflammatory, analgesic and antipyretic properties of Clitoria ternatea root. Fitoterapia 74, 345-349. doi: 10.1016/S0367-326X(03)00057-1

Duangkhet, M., Chikoti, Y., Thepsukhon, A., Thapanapongworakul, P., Chungopast, S., Tajima, S., et al. (2018). Isolation and characterization of rhizobia from nodules of Clitoria ternatea in Thailand. Plant Biotechnol. 35, 123-129. doi: 10.5511/plantbiotechnology.18.0402a

Dwivedi, G. K., and Kumar, D. (2001). Nitrogen economy, dry matter production and seed production potential of Setaria sphacelata by intercropping of pasture legumes. J. Agron. Crop Sci. 182, 121-126. doi: 10.1046/j.1439-037x.1999. 00275.x

Falck, G., and Müller, K. (2018). Enzyme-based labeling strategies for antibodydrug conjugates and antibody mimetics. Antibodies 7:4. doi: 10.3390/ antib7010004

Fantz, P. R. (1977). A Monograph of the Genus Clitoria (Leguminosae: Glycineae). Doctoral dissertation, University of Florida, Gainesville, FL.

Felizmenio-Quimio, M. E., Daly, N. L., and Craik, D. J. (2001). Circular proteins in plants: solution structure of a novel macrocyclic trypsin inhibitor from Momordica cochinchinensis. J. Biol. Chem. 276, 22875-22882. doi: 10.1074/jbc. M101666200

Gelly, J.-C., Gracy, J., Kaas, Q., Le-Nguyen, D., Heitz, A., and Chiche, L. (2004). The KNOTTIN website and database: a new information system dedicated to the knottin scaffold. Nucleic Acids Res. 32, D156-D159. doi: 10.1093/nar/gkh015

Gilding, E. K., Jackson, M. A., Poth, A. G., Henriques, S. T., Prentis, P. J., Mahatmanto, T., et al. (2015). Gene coevolution and regulation lock cyclic plant defence peptides to their targets. New Phytol. 210, 717-730. doi: 10.1111/nph. 13789

Goodstein, D. M., Shu, S., Howson, R., Neupane, R., Hayes, R. D., Fazo, J., et al. (2012). Phytozome: a comparative platform for green plant genomics. Nucleic Acids Res. 40, D1178-D1186. doi: 10.1093/nar/gkr944

Göransson, U., Malik, S., and Slazak, B. (2015). "Cyclotides in the Violaceae," in Advances in Botanical Research, ed. D. J. Craik (Cambridge, MA: Academic Press), 15-49. doi: 10.1016/bs.abr.2015.09.001

Grindley, D. N., Burden, E. H. W. J., and Akour, A. A. (1954). The seed oils of Clitoria ternatea and Entada phaseoloides. J. Sci. Food Agric. 5, 278-280. doi: 10.1002/jsfa.2740050605

Gruber, C. W., Cemažar, M., Clark, R. J., Horibe, T., Renda, R. F., Anderson, M. A., et al. (2007). A novel plant protein-disulfide isomerase involved in the oxidative folding of cystine knot defense proteins. J. Biol. Chem. 282, 20435-20446. doi: 10.1074/jbc.M700018200

Gruber, C. W., Elliott, A. G., Ireland, D. C., Delprete, P. G., Dessein, S., Göransson, U., et al. (2008). Distribution and evolution of circular miniproteins in flowering plants. Plant Cell 20, 2471-2483. doi: 10.1105/tpc.108.062331

Gründemann, C., Koehbach, J., Huber, R., and Gruber, C. (2012). Do plant cyclotides have potential as immunosuppressant peptides? J. Nat. Prod. 75, 167-174. doi: 10.1021/np200722w

Gründemann, C., Unutmaz, D., Thell, K., Lengen, K., Garcia-Käufer, M., Huang, Y.-H., et al. (2013). Cyclotides suppress human T-lymphocyte proliferation by an interleukin 2-dependent mechanism. PLoS One 8:68016. doi: 10.1371/ journal.pone.0068016

Habish, H., and Mahdi, A. (1983). Nodulation of legumes in the Sudan. IV. Effects of soil moisture, light and temperature on nodulation of Clitoria ternatea. East Afr. Agric. For. J. 44, 229-236. doi: 10.1080/00128325.1979.11663013

Hall, T. J. (1985). Adaptation and agronomy of Clitoria ternatea L. in Northern Australia. Trop. Grasslands 19, 156-163.

Harada, G., Onoue, S., Inoue, C., Hanada, S., and Katakura, Y. (2018). Delphinidin3-glucoside suppresses lipid accumulation in HepG2 cells. Cytotechnology 70, 1707-1712. doi: 10.1007/s10616-018-0246-0

Harmand, T. J., Bousbaine, D., Chan, A., Zhang, X., Liu, D. R., Tam, J. P., et al. (2018). One-pot dual labeling of IgG 1 and preparation of C-to-C fusion proteins through a combination of sortase A and butelase 1. Bioconjug. Chem. 29, 3245-3249. doi: 10.1021/acs.bioconjchem.8b00563

Harris, K. S., Durek, T., Kaas, Q., Poth, A. G., Gilding, E. K., Conlan, B. F., et al. (2015). Efficient backbone cyclization of linear peptides by a recombinant asparaginyl endopeptidase. Nat. Commun. 6:10199. doi: 10.1038/ ncomms10199

Hasan, N., and Jain, R. K. (1985). Preliminary assessment of the response of Clitoria ternatea lines to the root-knot nematode, Meloidogyne incognita. Nematologica 31, 236-238. doi: 10.1163/187529285X00319
Ismail, N., Rani, U., and Batra, A. (2012). High frequency in vitro shoot regeneration of Clitoria ternatea L. affected by different cultural conditions. Indian J. Biotechnol. 11, 210-214.

Jackson, M. A., Gilding, E. K., Shafee, T., Harris, K. S., Kaas, Q., Poon, S., et al. (2018). Molecular basis for the production of cyclic peptides by plant asparaginyl endopeptidases. Nat. Commun. 9:2411. doi: 10.1038/s41467-01804669-9

Jain, N. N., Ohal, C. C., Shroff, S. K., Bhutada, R. H., Somani, R. S., Kasture, V. S., et al. (2003). Clitoria ternatea and the CNS. Pharmacol. Biochem. Behav. 75, 529-536. doi: 10.1016/S0091-3057(03)00130-8

Jones, R. M., Bishop, H. G., Clem, R. L., Conway, M. J., Cook, B. G., Moore, K., et al. (2000). Measurements of nutritive value of a range of tropical legumes and their use in legume evaluation. Trop. Grasslands 34, 78-90.

Joshi, S. S., Shrivastava, R. K., and Shrivastava, D. K. (1981). Chemical examination of Clitoria ternatea seeds. J. Am. Oil Chem. Soc. 58, 714-715.

Jouvensal, L., Quillien, L., Ferrasson, E., Rahbé, Y., Guéguen, J., and Vovelle, F. (2003). PA1b, an insecticidal protein extracted from pea seeds (Pisum sativum): 1 H-2-D NMR study and molecular modeling. Biochemistry 42, 11915-11923. doi: 10.1021/bi0348031

Kamh, M., Abdou, M., Chude, V., Wiesler, F., and Horst, W. J. (2002). Mobilization of phosphorus contributes to positive rotational effects of leguminous cover crops on maize grown on soils from northern Nigeria. J. Plant Nutr. Soil Sci. 165, 566-572. doi: 10.1002/1522-2624(200210)165:5<566::aid-jpln566>3.0. co; 2 -o

Kamilla, L., Mansor, S. M., Ramanathan, S., and Sasidharan, S. (2009). Effects of Clitoria ternatea leaf extract on growth and morphogenesis of Aspergillus niger. Microsc. Microanal. 15, 366-372. doi: 10.1017/S1431927609090783

Kavitha, R. (2018). Biochemical studies on the effect of ethanolic extracts of Trichosanthes dioica and Clitoria ternatea in streptozotocin induced male Wistar rats. Int. J. Pharm. Sci. Res. 9, 4682-4689. doi: 10.13040/ijpsr.0975-8232. 9(11).4682-89

Kazuma, K., Kogawa, K., Noda, N., Kato, N., and Suzuki, M. (2004). Identification of delphinidin 3-O-(6'-O-malonyl)- $\beta$-glucoside- $3^{\prime}$-O- $\beta$-glucoside, a postulated intermediate in the biosynthesis of ternatin $\mathrm{C} 5$ in the blue petals of Clitoria ternatea (Butterfly Pea). Chem. Biodivers. 1, 1762-1770. doi: 10.1002/cbdv.200490132

Kazuma, K., Noda, N., and Suzuki, M. (2003a). Flavonoid composition related to petal color in different lines of Clitoria ternatea. Phytochemistry 64, 1133-1139. doi: 10.1016/S0031-9422(03)00504-1

Kazuma, K., Noda, N., and Suzuki, M. (2003b). Malonylated flavonol glycosides from the petals of Clitoria ternatea. Phytochemistry 62, 229-237. doi: 10.1016/ S0031-9422(02)00486-7

Kelemu, S., Cardona, C., and Segura, G. (2004). Antimicrobial and insecticidal protein isolated from seeds of Clitoria ternatea, a tropical forage legume. Plant Physiol. Biochem. 42, 867-873. doi: 10.1016/j.plaphy.2004.10.013

Khadatkar, S. N., Manwar, J., and Bhajipale, N. S. (2008). In-vitro anthelmintic activity of root of Clitoria ternatea Linn. Pharmacogn. Mag. 4, 148-150.

Koehbach, J., Attah, A. F., Berger, A., Hellinger, R., Kutchan, T. M., Carpenter, E. J., et al. (2013). Cyclotide discovery in Gentianales revisited-identification and characterization of cyclic cystine-knot peptides and their phylogenetic distribution in Rubiaceae plants. Biopolymers 100, 438-452. doi: 10.1002/bip. 22328

Koehbach, J., and Gruber, C. W. (2015). “Cyclotides in the Rubiaceae," in Advances in Botanical Research, ed. D. J. Craik (Cambridge, MA: Academic Press), 51-78. doi: 10.1016/bs.abr.2015.09.002

Kondo, T., Ueda, M., and Goto, T. (1990). Structure of ternatin B1, a pentaacylated anthocyanin substituted on the B-ring asymmetrically with two long chains. Tetrahedron 46, 4749-4756. doi: 10.1016/S0040-4020(01)85593-9

Kulshreshtha, D. K., and Khare, M. P. (1967). Chemical investigation of the seeds of Clitoria ternatea 'Linn'. Curr. Sci. 36, 124-125.

Kumar, V., Mukherjee, K., Kumar, S., Mal, M., and Mukherjee, P. K. (2008). Validation of HPTLC method for the analysis of taraxerol in Clitoria ternatea. Phytochem. Anal. 19, 244-250. doi: 10.1002/pca.1042

Kumari, N. V., and Devi, M. L. (2013). Effect of some indigenous plant extracts on the inhibition of egg hatching of nematode Meloidogyne incognita Chitwood infesting mulberry. HortFlora Res. Spec. 2, 35-39.

Lakshmanan, K. K., and Dhanalakshmi, S. (1990). Callus, organogenesis and plantlet formation in tissue cultures of Clitoria ternatea. Ann. Bot. 66, 451-455. doi: 10.1093/oxfordjournals.aob.a088047 
Lakshmanan, M., and Padmanabhan, D. (1968). Effect of ascochitine on the in vitro growth of embryos of Clitoria Ternatea L. Curr. Sci. 37, 321-322.

Liu, R., Mu, L., Liu, H., Wei, L., Yan, T., Chen, M., et al. (2011). Two antimicrobial and nematicidal peptides derived from sequences encoded Picea sitchensis. J. Pept. Sci. 17, 627-631. doi: 10.1002/psc.1380

Mahala, A. G., Amasiab, S. O., Yousif, M. A., and Elsadig, A. (2012). Effect of Plant age on DM yield and nutritive value of some leguminous plants (Cyamopsis tetragonoloba, Lablab purpureus and Clitoria (Clitoria ternatea). Int. Res. J. Agric. Sci. Soil Sci. 2, 502-508.

Mahmad, N., Taha, R. M., Othman, R., Elias, H., and Saleh, A. (2016). Encapsulated embryogenic callus of Clitoria ternatea L. for regeneration and conservation. Int. J. Environ. Sci. Dev. 7, 363-367. doi: 10.7763/ijesd.2016.v7.801

Maity, N., Nema, N., Sarkar, B., and Mukherjee, P. (2012). Standardized Clitoria ternatea leaf extract as hyaluronidase, elastase and matrix-metalloproteinase-1 inhibitor. Indian J. Pharmacol. 44, 584-587. doi: 10.4103/0253-7613.100381

McDonald, C. K. (2002). Germination response to temperature in tropical and subtropical pasture legumes. 1. Constant temperature. Aust. J. Exp. Agric. 42, 407-419.

Mensah, R., Leach, D., Young, A., Watts, N., and Glennie, P. (2015). Development of Clitoria ternatea as a biopesticide for cotton pest management: assessment of product effect on Helicoverpa spp. and their natural enemies. Entomol. Exp. Appl. 154, 131-145. doi: 10.1111/eea.12263

Mhaskar, A., Krishnan, P., Vishwakarma, K., and Maheshwari, V. (2011). In vitro regeneration of Clitoria ternatea $\mathrm{L}$. through axillary bud culture. Int. J. Pharmacol. Biol. Sci. 5, 17-23.

Mohamed, N., and Taha, R. M. (2011). Plant regeneration of Clitoria ternatea from leaf explants cultured in vitro. J. Food Agric. Environ. 9, 268-270.

Morita, N., Ariwasa, M., Nagase, M., Hsu, H.-Y., and Chen, Y.-P. (1976). Studies on the constituents of formosan leguminosae: the constituents in the leaves of Clitoria ternatea L. Yakugaku Zasshi 97, 649-653. doi: 10.1248/yakushi1947.97. 6 649

Morris, J. B. (2009). Characterization of butterfly pea (Clitoria ternatea L.) accessions for morphology, phenology, reproduction and potential nutraceutical, pharmaceutical trait utilization. Genet. Resour. Crop Evol. 56, 421-427. doi: 10.1007/s10722-008-9376-0

Mukherjee, P. K., Kumar, V., Kumar, N. S., and Heinrich, M. (2008). The Ayurvedic medicine Clitoria ternatea-from traditional use to scientific assessment. J. Ethnopharmacol. 120, 291-301. doi: 10.1016/j.jep.2008.09.009

Mukhtar, S., Ahmad, N., Khan, M. I., Anis, M., and Aref, I. M. (2012). Influencing micropropagation in Clitoria ternatea L. through the manipulation of TDZ levels and use of different explant types. Physiol. Mol. Biol. Plants 18, 381-386. doi: 10.1007/s12298-012-0136-4

Mullick, P., and Chatterji, U. N. (1967). Eco-physiological studies on seed germination: germination experiments with the seeds of Clitoria ternatea Linn. Trop. Ecol. 8, 116-125.

Mylne, J. S., Chan, L. Y., Chanson, A. H., Daly, N. L., Schaefer, H., Bailey, T. L., et al. (2012). Cyclic peptides arising by evolutionary parallelism via asparaginylendopeptidase-mediated biosynthesis. Plant Cell 24, 2765-2778. doi: 10.1105/ tpc.112.099085

Mylne, J. S., Colgrave, M. L., Daly, N. L., Chanson, A. H., Elliott, A. G., McCallum, E. J., et al. (2011). Albumins and their processing machinery are hijacked for cyclic peptides in sunflower. Nat. Chem. Biol. 7, 257-259. doi: 10.1038/ nchembio. 542

Nguyen, G. K., Kam, A., Loo, S., Jansson, A. E., Pan, L. X., and Tam, J. P. (2015). Butelase 1: a versatile ligase for peptide and protein macrocyclization. J. Am. Chem. Soc. 137, 15398-15401. doi: 10.1021/jacs.5b11014

Nguyen, G. K., Wang, S., Qiu, Y., Hemu, X., Lian, Y., and Tam, J. P. (2014). Butelase 1 is an Asx-specific ligase enabling peptide macrocyclization and synthesis. Nat. Chem. Biol. 10, 732-738. doi: 10.1038/nchembio.1586

Nguyen, G. K. T., Hemu, X., Quek, J. P., and Tam, J. P. (2016a). Butelase-mediated macrocyclization of d-amino-acid-containing peptides. Angew. Chem. 55, 12802-12806. doi: 10.1002/anie.201607188

Nguyen, K. N., Nguyen, G. K., Nguyen, P. Q., Ang, K. H., Dedon, P. C., and Tam, J. P. (2016b). Immunostimulating and gram-negative-specific antibacterial cyclotides from the butterfly pea (Clitoria ternatea). FEBS J. 283, 2067-2090. doi: $10.1111 /$ febs. 13720

Nguyen, G. K. T., Qiu, Y., Cao, Y., Hemu, X., Liu, C.-F., and Tam, J. P. (2016c). Butelase-mediated cyclization and ligation of peptides and proteins. Nat. Protoc. 11, 1977-1988. doi: 10.1038/nprot.2016.118
Nguyen, G. K. T., Zhang, S., Ngan, T. K. N., Phuong, Q. T. N., Chiu, M. S., Hardjojo, A., et al. (2011). Discovery and characterization of novel cyclotides originated from chimeric precursors consisting of albumin-1 chain a and cyclotide domains in the Fabaceae family. J. Biol. Chem. 286, 24275-24287. doi: 10.1074/jbc.M111.229922

Nigg, J., Lewis, K., Edinger, T., and Falk, M. (2011). Meta-analysis of attentiondeficit/hyperactivity disorder or attention-deficit/hyperactivity disorder symptoms, sestriction diet, and synthetic food color additives. J. Am. Acad. Child Adolesc. Psychiatry 51, 86-97. doi: 10.1016/j.jaac.2011.10.015

Njunie, M. N., Wagger, M. G., and Luna-Orea, P. (2004). Residue decomposition and nutrient release dynamics from two tropical forage legumes in a Kenyan environment. Agron. J. 96, 1073-1081. doi: 10.2134/agronj2004.1073

Oblisami, G. (1974). Studies on the rhizobium and nodulation pattern in a forage legume Clitoria ternatea. Proc. Indian Natl. Sci. Acad. B Biol. Sci. 40, 618-623.

Oram, R. N. (1992). Register of Australian herbage plant cultivars. Aust. J. Exp. Agric. 32, 547-548.

Pandeya, K., Tiwari, K. N., Singh, J., Dubey, D., and Prakash Verma, J. (2010). In vitro propagation of Clitoria ternatea L.: a rare medicinal plant. J. Med. Plants Res. 4, 664-668. doi: 10.5897/jmpr09.418

Parimaladevi, B., Boominathan, R., and Mandal, S. C. (2004). Evaluation of antipyretic potential of Clitoria ternatea L. extract in rats. Phytomedicine 11, 323-326. doi: 10.1078/0944711041495191

Park, S., Yoo, K.-O., Marcussen, T., Backlund, A., Jacobsson, E., Rosengren, K. J., et al. (2017). Cyclotide evolution: insights from the analyses of their precursor sequences, structures and distribution in violets (Viola). Front. Plant Sci. 8:2058. doi: 10.3389/fpls.2017.02058

Pasukamonset, P., Kwon, O., and Adisakwattana, S. (2016). Alginate-based encapsulation of polyphenols from Clitoria ternatea petal flower extract enhances stability and biological activity under simulated gastrointestinal conditions. Food Hydrocoll. 61, 772-779. doi: 10.1016/j.foodhyd.2016.06.039

Pasukamonset, P., Kwon, O., and Adisakwattana, S. (2017). Oxidative stability of cooked pork patties incorporated with Clitoria ternatea extract (blue pea flower petal) during refrigerated storage. J. Food Process. Preserv. 41:e12751. doi: $10.1111 /$ jfpp. 12751

Pasukamonset, P., Pumalee, T., Sanguansuk, N., Chumyen, C., Wongvasu, P., Adisakwattana, S., et al. (2018). Physicochemical, antioxidant and sensory characteristics of sponge cakes fortified with Clitoria ternatea extract. J. Food Sci. Technol. 55, 2881-2889. doi: 10.1007/s13197-018-3204-0

Patel, J., Pillai, V., Sharma, A., Dholakiya, B., Gajbhiye, N., and Saravanan, R. (2016). Effect of seed treatment on germination and flavonoids diversity in accessions of butterfly pea (Clitoria ternatea). Indian J. Agric. Sci. 86, 15531558.

Perry, T., Batterham, P., and Daborn, P. J. (2011). The biology of insecticidal activity and resistance. Insect Biochem. Mol. Biol. 41, 411-422. doi: 10.1016/j. ibmb.2011.03.003

Phrueksanan, W., Yibchok-anun, S., and Adisakwattana, S. (2014). Protection of Clitoria ternatea flower petal extract against free radical-induced hemolysis and oxidative damage in canine erythrocytes. Res. Vet. Sci. 97, 357-363. doi: 10.1016/j.rvsc.2014.08.010

Piala, J. J., Madissoo, H., and Rubin, B. (1962). Diuretic activity of roots of Clitoria ternatea L. in dogs. Experientia 18:89. doi: 10.1007/BF02138275

Plan, M. R. R., Göransson, U., Clark, R. J., Daly, N. L., Colgrave, M. L., and Craik, D. J. (2007). The cyclotide fingerprint in Oldenlandia affinis: elucidation of chemically modified, linear and novel macrocyclic peptides. ChemBioChem 8 , 1001-1011. doi: 10.1002/cbic.200700097

Poth, A. G., Colgrave, M. L., Lyons, R. E., Daly, N. L., and Craik, D. J. (2011a). Discovery of an unusual biosynthetic origin for circular proteins in legumes. Proc. Natl. Acad. Sci. U.S.A. 108, 10127-10132. doi: 10.1073/pnas.11036 60108

Poth, A. G., Colgrave, M. L., Philip, R., Kerenga, B., Daly, N. L., Anderson, M. A., et al. (2011b). Discovery of cyclotides in the Fabaceae plant family provides new insights into the cyclization, evolution, and distribution of circular proteins. ACS Chem. Biol. 6, 345-355. doi: 10.1021/cb100388j

Pullaiah, T. (2000). Embryology of Clitoria ternatea (Fabaceae). Plant Biosyst. 134, 39-43. doi: 10.1080/11263500012331350325

Raghu, K. S., Shamprasad, B. R., Kabekkodu, S. P., Paladhi, P., Joshi, M. B., Valiathan, M. S., et al. (2017). Age dependent neuroprotective effects of medhya rasayana prepared from Clitoria ternatea Linn. in stress induced rat brain. J. Ethnopharmacol. 197, 173-183. doi: 10.1016/j.jep.2016.07.068 
Rai, K., Murthy, D. S., Karanth, K., and Rao, M. (2001). Clitoria ternatea (Linn) root extract treatment during growth spurt period enhances learning and memory in rats. Indian J. Physiol. Pharmacol. 45, 305-313.

Rai, K. S., Murthy, K. D., Karanth, K. S., Nalini, K., Rao, M. S., and Srinivasan, K. K. (2002). Clitoria ternatea root extract enhances acetylcholine content in rat hippocampus. Fitoterapia 73, 685-689. doi: 10.1016/S0367-326X(02)00249-6

Rai, K. S., Murthy, K. D., Rao, M. S., and Karanth, K. S. (2005). Altered dendritic arborization of amygdala neurons in young adult rats orally intubated with Clitorea ternatea aqueous root extract. Phytother. Res. 19, 592-598. doi: 10.1002/ ptr. 1657

Reid, R., and Sinclair, D. F. (1980). An evaluation of C. ternatea for forage and grain production. Genet. Resour. Commun. 1, 1-8.

Rout, G. R. (2005). Micropropagation of Clitoria ternatea Linn. (Fabaceae)- An important medicinal plant. In Vitro Cell. Dev. Biol. Plant 41, 516-519. doi: 10.1079/IVP2005675

Saito, N., Abe, K., Honda, T., Timberlake, C. F., and Bridle, P. (1985). Acylated delphinidin glucosides and flavonols from Clitoria ternatea. Phytochemistry 24, 1583-1586.

Salhan, M., Kumar, B., Tiwari, P., Sharma, P., Sandhar, H. K., and Gautam, M. (2011). Comparative anthelmintic activity of aqueous and ethanolic leaf extracts of Clitoria ternatea. Int. J. Drug Dev. Res. 3, 68-69.

Serra, A., Hemu, X., Nguyen, G. K., Nguyen, N. T., Sze, S. K., and Tam, J. P. (2016). A high-throughput peptidomic strategy to decipher the molecular diversity of cyclic cysteine-rich peptides. Sci. Rep. 6:23005. doi: 10.1038/srep23005

Shahid, M., Shahzad, A., and Anis, M. (2009). Antibacterial potential of the extracts derived from leaves and in vitro raised calli of medicinal plants Pterocarpus marsupium Roxb., Clitoria ternatea L., and Sanseveiria cylindrica Bojer ex Hook. Orient. Pharm. Exp. Med. 9, 174-181. doi: 10.3742/OPEM.2009.9.2.174

Shahzad, A., Faisal, M., and Anis, M. (2007). Micropropagation through excised root culture of Clitoria ternatea and comparison between in vitro regenerated plants and seedlings. Ann. Appl. Biol. 150, 341-349. doi: 10.1111/j.1744-7348. 2007.00132.x

Singh, N. K., Garabadu, D., Sharma, P., Shrivastava, S. K., and Mishra, P. (2018). Anti-allergy and anti-tussive activity of Clitoria ternatea L. in experimental animals. J. Ethnopharmacol. 224, 15-26. doi: 10.1016/j.jep.2018. 05.026

Siti Azima, A. M., Noriham, A., and Manshoor, N. (2017). Phenolics, antioxidants and color properties of aqueous pigmented plant extracts: Ardisia colorata var. elliptica, Clitoria ternatea, Garcinia mangostana and Syzygium cumini. J. Funct. Foods 38, 232-241. doi: 10.1016/j.jff.2017.09.018

Sogo, T., Terahara, N., Hisanaga, A., Kumamoto, T., Yamashiro, T., Wu, S., et al. (2015). Anti-inflammatory activity and molecular mechanism of delphinidin 3sambubioside, a Hibiscus anthocyanin. BioFactors 41, 58-65. doi: 10.1002/biof. 1201

Solanki, Y. B., and Jain, S. M. (2010). Antihyperlipidemic activity of Clitoria ternatea and Vigna mungo in rats. Pharm. Biol. 48, 915-923. doi: 10.3109/ 13880200903406147

Staples, I. B. (1992). “Clitoria ternatea L," in Plant Resources of Southeast Asia, eds L. T. Mannetje and R. M. Jones (Wageningen: Pudoc Scientific Publishers).

Sushma, N. J., Prathyusha, D., Swathi, G., Madhavi, T., Raju, B. D. P., Mallikarjuna, K., et al. (2015). Facile approach to synthesize magnesium oxide nanoparticles by using Clitoria ternatea-characterization and in vitro antioxidant studies. Appl. Nanosci. 6, 437-444. doi: 10.1007/s13204-015-0455-1

Swain, S. S., Rout, K. K., and Chand, P. K. (2012a). Production of triterpenoid anti-cancer compound taraxerol in Agrobacterium-transformed root cultures of butterfly pea (Clitoria ternatea L.). Appl. Biochem. Biotechnol. 168, 487-503. doi: 10.1007/s12010-012-9791-8

Swain, S. S., Sahu, L., Pal, A., Barik, D. P., Pradhan, C., and Chand, P. K. (2012b). Hairy root cultures of butterfly pea (Clitoria ternatea L.): Agrobacterium x plant factors influencing transformation. World J. Microbiol. Biotechnol. 28, 729-739. doi: 10.1007/s11274-011-0869-1

Talpate, K., Bhosale, U., Zambare, M., and Somani, R. (2014). Neuroprotective and nootropic activity of Clitorea ternatea Linn.(Fabaceae) leaves on diabetes induced cognitive decline in experimental animals. J. Pharm. Bioallied Sci. 6, 48-55. doi: 10.4103/0975-7406.124317
Tani, T., Nishikawa, S., Kato, M., and Tsuda, T. (2017). Delphinidin 3-rutinosiderich blackcurrant extract ameliorates glucose tolerance by increasing the release of glucagon-like peptide-1 secretion. Food Sci. Nutr. 5, 929-933. doi: 10.1002/ fsn 3.478

Taranalli, A. D., and Cheeramkuzhy, T. C. (2000). Influence of Clitoria ternatea extracts on memory and central cholinergic activity in rats. Pharm. Biol. 38, 51-56. doi: 10.1076/1388-0209(200001)3811-BFT051

Taur, D. J., and Patil, R. Y. (2011). Evaluation of antiasthmatic activity of Clitoria ternatea L. roots. J. Ethnopharmacol. 136, 374-376. doi: 10.1016/j.jep.2011. 04.064

Taur, D. J., Taware, S. B., Patil, R. N., Patil, R. Y., and Kharya, M. D. (2010). Pharmacognostical and preliminary phytochemical evaluation of Clitoria ternatea leaves. Pharmacogn. J. 2, 260-265. doi: 10.1016/S0975-3575(10) 80114-2

Terahara, N., Oda, M., Matsui, T., Osajima, Y., Saito, N., Toki, K., et al. (1996). Five new anthocyanins, ternatins A3, B4, B3, B2, and D2, from Clitoria ternatea flowers. J. Nat. Prod. 59, 139-144. doi: 10.1021/np960050a

Terahara, N., Saito, N., Honda, T., Toki, K., and Osajima, Y. (1989a). Structure of ternatin A1, the largest ternatin in the major blue anthocyanins from Clitoria ternatea flowers. Tetrahedron Lett. 31, 2921-2924. doi: 10.1016/0040-4039(90) 80185-O

Terahara, N., Saito, N., Honda, T., Toki, K., and Osajima, Y. (1989b). Structure of ternatin D1, an acylated anthocyanin from Clitoria ternatea flowers. Tetrahedron Lett. 30, 5305-5308. doi: 10.1016/S0040-4039(01)93771-2

Terahara, N., Saito, N., Honda, T., Toki, K., and Osajima, Y. (1990a). Acylated anthocyanins of Clitoria ternatea flowers and their acyl moieties. Phytochemistry 29, 949-953. doi: 10.1016/0031-9422(90)80053-J

Terahara, N., Saito, N., Honda, T., Toki, K., and Osajima, Y. (1990b). Further structural elucidation of the anthocyanin, deacylternatin, from Clitoria ternatea. Phytochemistry 29, 3686-3687. doi: 10.1016/0031-9422(90)85308-3

Terahara, N., Saito, N., Honda, T., Toki, K., and Osajima, Y. (1990c). Structure of ternatin A2, one of Clitoria ternatea flower anthocyanins having the unsymmetrical side chains. Heterocycles 31, 1773-1776. doi: 10.3987/COM-905544

Terahara, N., Toki, K., Saito, N., Honda, T., Matsui, T., and Osajima, Y. (1998). Eight new anthocyanins, ternatins C1-C5 and D3 and preternatins A3 and C4 from young Clitoria ternatea flowers. J. Nat. Prod. 61, 1361-1367. doi: $10.1021 / \mathrm{np} 980160 \mathrm{c}$

Thell, K., Hellinger, R., Sahin, E., Michenthaler, P., Gold-Binder, M., Haider, T., et al. (2016). Oral activity of a nature-derived cyclic peptide for the treatment of multiple sclerosis. Proc. Natl.Acad. Sci. U.S.A. 113, 3960-3965. doi: 10.1073/ pnas.1519960113

Vasisht, K., Dhobi, M., Khullar, S., Mandal, S. K., and Karan, M. (2016). Norneolignans from the roots of Clitoria ternatea L. Tetrahedron Lett. 57, 1758-1762. doi: 10.1016/j.tetlet.2016.03.024

Yamada, K., Shimada, T., Nishimura, M., and Hara-Nishimura, I. (2005). A VPE family supporting various vacuolar functions in plants. Physiol. Plant 123, 369-375. doi: 10.1111/j.1399-3054.2005.00464.x

Zaroug, M. G., and Munns, D. N. (1980a). Effects of phosphorus and sulfur nutrition on soluble sugars and growth in Clitoria ternatea L. Plant Soil 55, 243-250. doi: 10.1007/BF02181804

Zaroug, M. G., and Munns, D. N. (1980b). Screening strains of Rhizobium for the tropical legumes Clitoria ternatea and Vigna trilobata in soils of different $\mathrm{pH}$. Trop. Grasslands 14, 28-33.

Conflict of Interest Statement: The authors declare that the research was conducted in the absence of any commercial or financial relationships that could be construed as a potential conflict of interest.

Copyright (c) 2019 Oguis, Gilding, Jackson and Craik. This is an open-access article distributed under the terms of the Creative Commons Attribution License (CC BY). The use, distribution or reproduction in other forums is permitted, provided the original author(s) and the copyright owner(s) are credited and that the original publication in this journal is cited, in accordance with accepted academic practice. No use, distribution or reproduction is permitted which does not comply with these terms. 